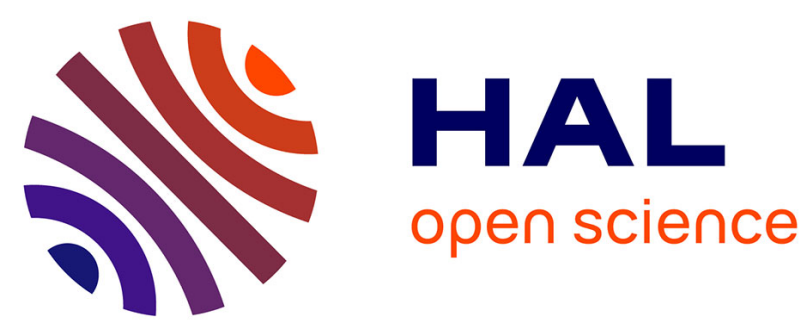

\title{
Correlation between the mechanical and histological properties of liver tissue
}

Berkay Yarpuzlu, Mehmet Ayyildiz, Olgu Enis Tok, Ranan Gulhan Aktas, Cagatay Basdogan

\section{- To cite this version:}

Berkay Yarpuzlu, Mehmet Ayyildiz, Olgu Enis Tok, Ranan Gulhan Aktas, Cagatay Basdogan. Correlation between the mechanical and histological properties of liver tissue. Journal of the mechanical behavior of biomedical materials, 2014, 29, pp.403-416. 10.1016/j.jmbbm.2013.09.016 . hal-03177337

\section{HAL Id: hal-03177337 \\ https://hal.science/hal-03177337}

Submitted on 23 Mar 2021

HAL is a multi-disciplinary open access archive for the deposit and dissemination of scientific research documents, whether they are published or not. The documents may come from teaching and research institutions in France or abroad, or from public or private research centers.
L'archive ouverte pluridisciplinaire HAL, est destinée au dépôt et à la diffusion de documents scientifiques de niveau recherche, publiés ou non, émanant des établissements d'enseignement et de recherche français ou étrangers, des laboratoires publics ou privés. 
archives-ouvertes

\section{Correlation between the mechanical and histological properties of liver tissue}

Berkay Yarpuzlu, Mehmet Ayyildiz, Olgu Enis Tok, Ranan Gulhan Aktas, Cagatay Basdogan

\section{To cite this version:}

Berkay Yarpuzlu, Mehmet Ayyildiz, Olgu Enis Tok, Ranan Gulhan Aktas, Cagatay Basdogan. Correlation between the mechanical and histological properties of liver tissue. Journal of the mechanical behavior of biomedical materials, Elsevier, 2014, 29, pp.403-416. 10.1016/j.jmbbm.2013.09.016 . hal03177337

\section{HAL Id: hal-03177337 \\ https://hal.archives-ouvertes.fr/hal-03177337}

Submitted on 23 Mar 2021

HAL is a multi-disciplinary open access archive for the deposit and dissemination of scientific research documents, whether they are published or not. The documents may come from teaching and research institutions in France or abroad, or from public or private research centers.
L'archive ouverte pluridisciplinaire HAL, est destinée au dépôt et à la diffusion de documents scientifiques de niveau recherche, publiés ou non, émanant des établissements d'enseignement et de recherche français ou étrangers, des laboratoires publics ou privés. 


\title{
Correlation between the Mechanical and Histological Properties of Liver Tissue
}

\author{
Berkay Yarpuzlu ${ }^{1}$, Mehmet Ayyildiz ${ }^{1}$, \\ Olgu Enis Tok ${ }^{2}$, Ranan Gulhan Aktas ${ }^{2}$, Cagatay Basdogan ${ }^{1 *}$ \\ ${ }^{1}$ College of Engineering, Koç University, Istanbul \\ ${ }^{2}$ School of Medicine, Koç University, Istanbul
}

*Corresponding author: Email address: cbasdogan@ku.edu.tr. Address: College of Engineering, Koc University, Istanbul, 34450, Turkey.

Tel.: +90212338 1721; Fax: +902123381548

\begin{abstract}
In order to gain further insight into the mechanisms of tissue damage during the progression of liver diseases as well as the liver preservation for transplantation, an improved understanding of the relation between the mechanical and histological properties of liver is necessary. We suggest that this relation can only be established truly if the changes in the states of those properties are investigated dynamically as a function of elapsed "time". In this regard, we first perform mechanical characterization experiments on three bovine livers to investigate the changes in gross mechanical properties (stiffness, viscosity, and fracture toughness) for the preservation periods of 5, 11, 17, 29, 41 and 53 hours after the harvesting. Then, histological examination is performed on the samples taken from the same livers to investigate the changes in apoptotic cell count, collagen accumulation, sinusoidal dilatation, and glycogen deposition as a function of the same preservation periods. Finally, the correlation between the mechanical and histological properties is investigated via Spearman's Rank-Order Correlation method. The results of our study show that stiffness, viscosity, fracture toughness of bovine liver increase as the preservation period is increased. These macroscopic changes are very strongly correlated with the increase in collagen accumulation and decrease in deposited glycogen level at the microscopic level. Also, we observe that the largest changes in mechanical and histological properties occur after the first 11-17 hours of preservation.
\end{abstract}

Keywords: bovine liver, material characterization, hyperelasticity, viscoelasticity, fracture toughness, finite element modeling, histology, mechanobiology. 


\section{Introduction}

Liver plays a major role in metabolism and acts as a source of energy for the body by storing glycogen. In addition, working with other systems and organs, it is responsible for several important functions such as storing iron, detoxifying harmful substances, maintaining the hormonal balance, producing bile to help with the digestion, regulating blood clotting, and producing immune factors to fight infections. Due to its multiple functions and strategic connections with the other organs, the liver is also prone to many diseases such as hepatitis, fatty liver, cirrhosis, and cancer. In order to diagnose a liver disease, in addition to some other medical tests, the level of fibrosis is measured. Liver fibrosis is associated with major alterations in both the quantity and composition of ECM (extracellular matrix). Fibrotic liver contains more ECM than normal one, including fibronectin, undulin, elastin, laminin, hyaluronan, proteoglycans, and especially collagen fibers. In fact, liver fibrosis is considered as the net result of the imbalance between the collagen fiber synthesis and decomposition. When fiber synthesis is very active and the decomposition is suppressed, then apoptosis is induced and liver fibrosis advances. If the progression of disease becomes severe, then liver failure occurs. Currently, the progression of liver disease is quantified by a liver biopsy, followed by a histological examination under a light microscope (Cui et al. 2010; Rockey et al. 2009). Specific staining of ECM fibers is used to quantify the degree of liver fibrosis using computer-guided morphometric analysis. The liver biopsy is an invasive procedure with many disadvantages including the possibility of causing bleeding, allergic reactions, and renal failure on the patient. Additionally, the operation can be risky for patients who have blood disorders and congestive heart failures. Therefore, non-invasive measurement and diagnosis of liver diseases is desirable. One of the challenges in this regard is to establish a correlation between the material properties of liver measured non-invasively and its histological states. Medical imaging techniques based on transient ultrasound elastography, called FibroScan 
(Sandrin et al., 2003, Ziol et al., 2005) and Magnetic Resonance Elastography, MRE, (Manduca et al., 2001, Huwart et al. 2006) have been utilized to quantify liver fibrosis noninvasively. In both approaches, the material properties of liver measured at a certain frequency of stimulation have been correlated with the fibrosis scores obtained from large patient groups for validation. FibroScan and MRE measurements have demonstrated the increase in elastic modulus of liver tissue with an increase in fibrosis level. These measurements are performed externally without having any direct contact with the actual liver tissue. In addition to the medical imaging techniques, mechanical characterization techniques have been also utilized to correlate material properties of liver with fibrosis levels. Mazza et al. (2007) conducted in vivo and ex vivo experiments with 10 human subjects having some liver pathology. Static mechanical properties were measured invasively on diseased liver segments using an aspiration device and fibrotic tissue is found 3 times stiffer than the normal tissue. Ozcan et al. (2011) performed invasive experiments with an impact hammer on 15 human livers, harvested from the patients having some form of liver disease, to investigate the frequency-dependent dynamic material properties of liver tissue as a function of liver fibrosis. They also observed an increase in elastic (storage) modulus of human liver as a function of increase in fibrosis level, characterized by histological scoring. Egena et al. (2012) correlated the stiffness and viscosity of the bovine liver cells with fibrosis level. The presence of live and dead cells, and the size distributions were measured. They suggested that tuning in liver stiffness could play an essential role in the control of primary liver tumors. Lake et al. (2012) investigated the collagen alignment on the mechanical and structural behavior of liver tissue subjected to compression. They observed that there is no significant difference between the mechanical peak responses, but there is a significant difference between stress relaxation responses of samples with different alignments. 
In the studies discussed above, the mechanical properties have been correlated with fibrosis scores to diagnose a disease or its severity. However, the fibrosis scores utilized in those studies do not really represent measurements of a continuous variable, but rather a degree of severity at a certain state of disease. As a result, the dynamic relation between the mechanical and histological properties has not been established. Moreover, the terminology used in histological examination is not precise; the scoring mostly relies on qualitative descriptions rather than quantitative measurements. There are problems in obtaining reproducible scores, since the process heavily relies on the expertise of the examiner (Shiha and Zalata, 2011). In this paper, we propose quantitative techniques to investigate the relation between mechanical and histological properties of liver to gain further insight into the mechanisms of tissue damage during the progression of liver diseases.

Another area where this insight can be helpful is the liver transplantation. The transplantation is the only treatment available today for severe liver failure. In this process, the diseased liver is replaced with a healthy one harvested from a donor. The liver harvested from a donor must be well preserved and then transported to the recipient immediately. Along this process, tissue damage occurs in the liver due to the drop in its temperature (hypothermia) and insufficient supply of blood to its vessels (ischemia). In order to preserve the liver during transportation, it is placed in a bag containing a chemical solution covered with ice. While the chemical solutions suggested in the literature for preserving a liver differ in components, they all aim to delay cell death (apoptosis), which is inevitable (Guibert et al. 2011). During apoptosis, morphological changes in ECM structure and cell shape such as shrinkage and bulging are observed. Additionally, due to the ischemia, the endothelial cells start to die, triggering hepatic sinusoidal dilatation. The glycogen stored in the tissue is consumed by the living cells to obtain additional energy during this preservation period, resulting in a decrease in the glycogen level of tissue (Corps et al. 2009; Jain et al. 2004; Natori et al. 1999). All 
these changes in histology of liver can be detected via specialized stains and quantified by image processing tools under light microscope. However, there is no consensus among the surgeons and experts on how long the preservation period must be. Again, investigating the changes in mechanical and histological properties as a function of preservation time and the correlation between them can provide insight into a) how long a liver can be preserved before it is transplanted to a recipient and b) how to design the chemical solutions to elongate the preservation period.

In summary, although there are studies available about the mechanical and histological properties of liver separately, the number of studies in the literature investigating the correlation between them is very limited. Moreover, in the existing studies, no attention has been paid to the "dynamical" changes in those properties as a function of "time". In this study, we investigate the correlation between the changes in gross mechanical and histological properties of liver tissue as a function of preservation time. This approach is inspired by the dynamical systems theory, where the continuous behavior of a complex dynamical system is investigated as a function of time.

Mechanical characterization experiments and histological examination are performed on 3 bovine livers 5, 11, 17, 29, 41 and 53 hours after harvesting. First, static indentation and ramp-and-hold experiments are performed on each liver with a round probe to estimate its hyper-viscoelastic material properties for different preservation periods. Then, needle insertion experiments are performed on the same liver with a sharp probe to estimate its fracture toughness. A finite element (FE) model of bovine liver developed in ANSYS and an inverse FE analysis is performed on the model to estimate the material properties of each liver (Samur et al., 2007, Gokgol et al., 2012). To investigate the histological properties, the tissue samples taken from the same livers are stained with different methods. They are labeled with Tunel detection apoptosis kit to count the number of apoptotic cells. Masson`s trichrome stain 
is used to measure the amount of collagen accumulation. Glycogen deposition is investigated with Periodic Acid Schiff reagent. Sinusoidal dilatation, another histopathologic change in liver, is examined with Hematoxylene \& Eosin stain. Following the measurement of mechanical and the histological properties as a function of the preservation time, the correlation between them is investigated via Spearman's Rank-Order correlation method. Moreover, a sensitivity analysis is performed on the mechanical and histological properties to determine the critical period of preservation based on the largest change in the properties.

\section{Materials and Methods}

\subsection{Preparation of livers for mechanical characterization}

In this study, experiments are performed on 3 bovine livers to investigate the relation between the mechanical and the histological properties of liver tissue as a function of elapsed time. The livers are preserved in Lactated Ringer's solution at $+4^{\circ} \mathrm{C}$ immediately after the harvesting. The right lobe of each liver is detached from the whole liver with the help of a sharp knife and all the experiments are performed on this lobe (Figure 1). The transfer of the livers from the slaughterhouse to our laboratory took 4 hours and the preparation for the experiments took another hour following the transfer. Three sets of mechanical experiments (static indentation, ramp-and-hold, and needle insertion) are performed on each liver 5, 11, 17, 29, 41 and 53 hours after harvesting using the experimental setup developed in our laboratory (Ocal et al., 2010). This setup consists of a step motor, a power screw, a moving nut on the power screw, a probe/needle on the nut, and a force sensor (Figure 2A).

\subsection{Static indentation experiments}

Static indentation experiments are performed on the livers to investigate their straindependent hyperelastic material properties (Figure 3). Each liver is compressed to $20 \mathrm{~mm}$ 
depth with the aid of a cylindrical probe (Figure 2B) at a slow rate of $0.5 \mathrm{~mm} / \mathrm{s}$ to minimize the dynamic effects. The force response of liver tissue is measured as a function of the compression depth.

\subsection{Ramp-and-hold experiments}

Ramp-and-hold experiments are performed on the livers to investigate their timedependent viscoelastic material properties. First, each liver is compressed to $20 \mathrm{~mm}$ depth at a rate of $48 \mathrm{~mm} / \mathrm{s}$ using the cylindrical probe. Then, the probe is hold at that position for 600 seconds and the force response of the liver tissue is measured as a function of relaxation time.

\subsection{Needle insertion experiments}

Needle insertion experiments are performed on the livers with a sharp needle to estimate their fracture toughness. The needle is penetrated into $20 \mathrm{~mm}$ depth with a rate of $3 \mathrm{~mm} / \mathrm{s}$ and the force response is measured as a function of the penetration depth. Following a brief period of relaxation, the needle is retracted from the liver, only to be inserted once more into the same hole to measure the force response again. The fracture toughness is estimated from these two consecutive measurements using the energy-based fracture mechanics approach (Gokgol et al., 2012).

\subsection{Characterization of Material Properties}

Since the mechanical characterization experiments are performed with a thin cylindrical probe on the livers having large surface, it is not possible to obtain hyperviscoelastic material properties directly from the measurements. For this reason, first, a FE model of liver (Figure 4) is constructed in ANSYS from axisymmetric 2D elements having homogeneous, isotropic, hyper-viscoelastic, and nearly incompressible material properties and then, an inverse $\mathrm{FE}$ analysis is performed on the model to extract the material properties of the 
livers by inputting the measured experimental data (Samur et al., 2007; Gokgol et al, 2012). In order to reduce the number of FE computations, a two-dimensional FE model is preferred over a three-dimensional one, only the region around the contact is considered in the analysis, and the solution is assumed to be symmetric with respect to the axis of loading. The base of the FE mesh is constrained to have zero displacement.

The hyperelastic behavior of the livers is modeled using the Mooney-Rivlin strain energy function having 5 terms:

$W=C_{10}\left(I_{1}-3\right)+C_{01}\left(I_{2}-3\right)+C_{20}\left(I_{1}-3\right)^{2}+C_{11}\left(I_{1}-3\right)+C_{02}\left(I_{2}-3\right)^{2}$

where, $\mathrm{C}_{10}, \mathrm{C}_{01}, \mathrm{C}_{20}, \mathrm{C}_{11}$ and $\mathrm{C}_{02}$ are the hyperelastic material coefficients, and $\mathrm{I}_{1}$ and $\mathrm{I}_{2}$ are the principle invariants.

A Generalized Maxwell Solid (GMS) is used to model the viscoelastic behavior of the livers (Ocal et al., 2010). Then, the time-dependent relaxation of the livers under ramp-andhold strain input can be expressed analytically as:

$$
E_{R}(t)=E_{0}\left[1-\sum_{j=1}^{N} \alpha_{j}\right]+E_{0} \sum_{j=1}^{N} \alpha_{j} e^{-t / \tau_{j}}
$$

where, $E_{0}$ is the short-term elastic modulus, $\alpha_{j}$ represents the relative modulus, $\tau_{j}$ stands for the time constant, and $\mathrm{N}$ is the number of Maxwell arms used in the GMS model.

The hyperelastic material coefficients $\left(\mathrm{C}_{10}, \mathrm{C}_{01}, \mathrm{C}_{20}, \mathrm{C}_{11}\right.$ and $\left.\mathrm{C}_{02}\right)$ and the viscoelastic material coefficients for $\mathrm{N}=3\left(\alpha_{1}, \tau_{1}, \alpha_{2}, \tau_{2}, \alpha_{3}, \tau_{3}\right)$ are determined by the inverse FE analysis in ANSYS through optimization iterations (Samur et al., 2007, Gokgol et al., 2012). The optimization algorithm minimizes the force error defined as:

$$
\text { Error }=\sum_{j=1}^{M}\left(F_{j}^{E X P}-F_{j}^{F E M}\right)^{2}
$$


where, $M$ represents the number of data samples taken to represent the force curves, $F_{j}^{E X P}$ is the experimental force value of the $\mathrm{j}^{\text {th }}$ sample, and $\mathrm{F}_{\mathrm{j}}^{\mathrm{FEM}}$ is the force value obtained from the FE solution at the corresponding time step. The inverse solution is iterated until the total error in force is less than $0.1 \mathrm{~N}$.

The fracture toughness of each bovine liver is calculated using the energy-based fracture mechanics approach. The data (force versus penetration depth) collected via two consecutive needle insertions is used for the analysis (Gokgol et al., 2012). The energy balance for the first insertion is:

$F_{1} d u=J d A+d \Delta+P d u$

where, $F_{1}$ is the force acting on the needle during the first insertion, du is the change in the needle displacement, $\mathrm{J}$ is the fracture toughness (material property), $\mathrm{dA}$ is the change in crack area, JdA is the fracture work, $\mathrm{d} \Delta$ is the change in strain energy, $\mathrm{P}$ is the frictional force and Pdu is the work done by the friction. During the second insertion, the needle is inserted to the same spot and no rupture occurs. Hence, the energy balance for the second insertion is:

$F_{2} d u=d \Delta+P d u$

where, $F_{2}$ is the force acting on the needle during the second insertion, which is less than $F_{1}$. The change in strain energy, $\mathrm{d} \Delta$, and the work done by the friction, Pdu, are the same for the both insertions. The fracture toughness, $\mathrm{J}$, is obtained by subtracting Equation 5 from Equation 4 as:

$J=\int\left(F_{1}-F_{2}\right) d u / \int d A$ 


\subsection{Histological Examination}

Small tissue blocks, $3 \mathrm{~mm}$ in thickness, are obtained from each liver at different preservation periods for histological examination. The samples are fixed in $10 \%$ neutral buffered formalin for 24 hours at room temperature to preserve their structure. After the fixation, the samples are dehydrated by bathing them in a graded series of mixtures of ethanol and water. This is followed by a hydrophobic clearing agent (xylene) to remove the alcohol, and finally the infiltration agent (paraffin wax), which replaces the xylene. Then, the samples in paraffin wax are heated in the oven at $60^{\circ} \mathrm{C}$ for 2 hours. Finally, tissue samples are embedded in paraffin. Samples from each specimen are sectioned at 7-10 $\mu \mathrm{m}$ in thickness using a microtome (Leica M72S).

The sections are stained with three different stains for the histological examination: 1) Hematoxylene (Hematoxylene solution modified to Gill III, Merck) \& Eosin (Eosin Y solution $0.5 \%$ alcoholic, Merck) (H\&E) is utilized for the detection of the structural changes in sinusoids, 2) Masson`s Trichrome stain (Masson-Goldner Staining kit, Merck) is utilized to detect the changes in connective tissue and to investigate collagen accumulation, and 3) Periodic-Acid Schiff stain (PAS Staining kit, Merck) is utilized to visualize the changes in glycogen deposition in the cytoplasm of the liver cells.

Additionally, hepatocytes, which are undergoing apoptosis, are examined by using Apop Tag Plus Peroxidase Kit (Intergen S 7101, Millipore). This kit helps to determine DNA fragmentation in the cells, which is known as TUNEL (Terminal deoxynucleotidyl transferase dUTP nick end labeling) technique.

All treated sections are examined under Axiovision Zeiss light microscope. Microscopic images are captured from ten different areas on each section at $100 \mathrm{X}$ magnification (Carl Zeiss, Imager M1). Four scripts are designed in AxioVision image 
analysis software (Zeiss) for the analysis. These scripts enable us 1) to count the nuclei of apoptotic cells (stained as brown/dark brown with Apo Tag Plus Peroxidase kit) and 2) to measure the accumulation of collagen on each section stained with Masson`s trichrome, 3) to measure the area of sinusoids on each section stained with H\&E, and 4) the amount of glycogen deposition in the cells on each section stained with PAS.

\section{Results}

\subsection{Material Properties}

The average force response of the livers as a function of the compression depth are plotted in Figure 5A for different preservation periods. The hyperelastic material coefficients of the livers $\left(\mathrm{C}_{10}, \mathrm{C}_{01}, \mathrm{C}_{20}, \mathrm{C}_{11}\right.$, and $\left.\mathrm{C}_{02}\right)$ estimated through the inverse $\mathrm{FE}$ solution are tabulated in Table 1. The linear elastic modulus (Young's modulus) of the livers for small strain (the last column in Table 1) is calculated by $E=6\left(C_{10}+C_{01}\right)$. The change in the linear elastic modulus as a function of preservation period is shown in Figure 5B.

The viscoelastic material coefficients of the livers $\left(\alpha_{1}, \tau_{1}, \alpha_{2}, \tau_{2}, \alpha_{3}, \tau_{3}\right)$ estimated through the inverse FE solution are tabulated in Table 2. The settling time of the force response is estimated from the relaxation curve by defining a percent relative error as $R E=$ $100\left(F_{R}(t)-F_{\infty}\right) / F_{\infty}$. The relative error is chosen as $\mathrm{RE}=5 \%$. The normalized force relaxation response of the bovine livers and the change in settling time as a function of the preservation period are shown in Figure 6.

The fracture toughness $(\mathrm{J})$ of each liver is estimated from the data collected by two consecutive needle insertions. The force displacement responses of the liver of Animal \#1 during the first and second needle insertions are shown in Figure 7A. As shown in the figure, the curves are parallel following the initial rupture (see the sudden drop in force response in 
Figure 7A). The fracture toughness of the liver is estimated by first integrating this difference over the needle displacement and then dividing it by the crack area (the circumference of the probe times the penetration depth). The change in fracture toughness of the bovine livers as a function of preservation period is plotted in Figure 7B.

\subsection{Histological Properties}

The changes in histological properties of the bovine livers as a function of preservation period are tabulated in Table 3 .

The exemplar images of the tissue sections stained by the TUNEL technique (brown/dark brown) are shown in Figure 8A and 8C for PT $=5$ hrs and $53 \mathrm{hrs}$ respectively, and the corresponding images showing the cells marked on micrographs are shown in Figure $8 \mathrm{~B}$ and $8 \mathrm{D}$. The apoptotic cells are counted at ten different areas on each tissue section. The change in the number of apoptotic cells of the bovine livers as a function of preservation period is plotted in Figure 8E.

The examination of the sectioned stained with Masson`s trichrome reveals that connective tissue increases as a function of preservation time (Figure 9A and 9C). Using the image analysis software, the collagen accumulated regions (green colored) are measured (Figure 9B and 9D). The change in the connective tissue (especially, the collagen) of the bovine livers as a function of preservation period is plotted in Figure 9E.

The examination of the sections stained with H\&E (outlined with red color) reveals that sinusoidal dilatation is observable only in some areas (Figure 10A and 10C). Using the image analysis software, the borders of the sinusoids are outlined first, and then the areas enclosed by these borders are measured (Figure 10B and 10D). The change in the sinusoidal dilatation of the bovine livers as a function of preservation time is plotted in Figure 10E. 
The glycogen accumulation in the liver cells has been investigated with the help of PAS stain. As shown in Figure 11, the glycogen accumulation in the cytoplasm of the cells preserved for PT $=53$ hrs (Figure 11C) is significantly lower than that of PT $=5$ hrs (Figure 11A). The image analysis software labels blue-magenta stained regions on these sections first and then calculates their areas (Figure 11B and 11D). The change in the deposited glycogen level in the cells of the bovine livers as a function of preservation period is plotted in Figure $11 \mathrm{E}$.

Following the characterization of material and histological properties, the correlation between them is investigated via the Spearman's Rank-Order Correlation method. Spearman's Rank-Order Correlation is a measure of a monotronic relationship between two data sets. The significance level is chosen as $p=0.05$. The correlation coefficients, $r_{s}$, and the strength of the correlation between mechanical and histological properties are presented in Table 4. The correlation coefficients, $r_{s}$, and the strength of correlation (0-0.19: 'very weak', 0.20-0.39: 'weak', 0.40-0.59: 'moderate', 0.60-0.79: 'strong', 0.80-1.0: 'very strong', SI: Statistically Insignificant) between the mechanical and histological properties of bovine liver.

\begin{tabular}{|c|c|c|c|c|c|c|c|}
\hline $\begin{array}{c}\text { Correlation } \\
\text { Coefficient } \\
\left(\mathrm{r}_{\mathrm{s}}\right)\end{array}$ & $\begin{array}{c}\text { Apoptotic } \\
\text { Cell } \\
\text { Count }\end{array}$ & $\begin{array}{c}\text { Connective } \\
\text { Tissue }\end{array}$ & $\begin{array}{l}\text { Sinusoidal } \\
\text { Dilatation }\end{array}$ & $\begin{array}{c}\text { Glycogen } \\
\text { Deposition }\end{array}$ & $\begin{array}{l}\text { Young's } \\
\text { Modulus }\end{array}$ & $\begin{array}{c}\text { Fracture } \\
\text { Toughness }\end{array}$ & $\begin{array}{l}\text { Settling } \\
\text { Time }\end{array}$ \\
\hline $\begin{array}{c}\text { Apoptotic } \\
\text { Cell } \\
\text { Count }\end{array}$ & - & 0.84 & SI & -0.48 & 0.51 & 0.68 & 0.69 \\
\hline $\begin{array}{l}\text { Connective } \\
\text { Tissue }\end{array}$ & $\begin{array}{l}\text { Very } \\
\text { Strong }\end{array}$ & - & SI & -0.66 & 0.74 & 0.80 & 0.83 \\
\hline $\begin{array}{l}\text { Sinusoidal } \\
\text { Dilatation }\end{array}$ & SI & SI & - & -0.53 & SI & SI & SI \\
\hline $\begin{array}{l}\text { Glycogen } \\
\text { Deposition }\end{array}$ & Moderate & Strong & Moderate & - & -0.90 & -0.92 & -0.87 \\
\hline
\end{tabular}




\begin{tabular}{cccccccc}
\hline $\begin{array}{c}\text { Young's } \\
\text { Modulus }\end{array}$ & Moderate & Strong & SI & $\begin{array}{c}\text { Very } \\
\text { Strong }\end{array}$ & - & 0.87 & 0.81 \\
\hline $\begin{array}{c}\text { Fracture } \\
\text { Toughness }\end{array}$ & Strong & $\begin{array}{c}\text { Very } \\
\text { Strong }\end{array}$ & SI & $\begin{array}{c}\text { Very } \\
\text { Strong }\end{array}$ & $\begin{array}{c}\text { Very } \\
\text { Strong }\end{array}$ & - & 0.90 \\
\hline $\begin{array}{c}\text { Settling } \\
\text { Time }\end{array}$ & Strong & $\begin{array}{c}\text { Very } \\
\text { Strong }\end{array}$ & SI & $\begin{array}{c}\text { Very } \\
\text { Strong }\end{array}$ & $\begin{array}{c}\text { Very } \\
\text { Strong }\end{array}$ & $\begin{array}{c}\text { Very } \\
\text { Strong }\end{array}$ & - \\
\hline
\end{tabular}

Table 5.

Moreover, a sensitivity analysis is performed on the mechanical and histological properties of the liver to determine the critical period of preservation based on the largest change in the properties for unit change in preservation time (Table 4. The correlation coefficients, $\mathrm{r}_{\mathrm{s}}$, and the strength of correlation (0-0.19: 'very weak', 0.20-0.39: 'weak', 0.400.59: 'moderate', 0.60-0.79: 'strong', 0.80-1.0: 'very strong', SI: Statistically Insignificant) between the mechanical and histological properties of bovine liver.

\begin{tabular}{cccccccc}
\hline $\begin{array}{c}\text { Correlation } \\
\text { Coefficient } \\
\left(\mathrm{r}_{\mathrm{s}}\right)\end{array}$ & $\begin{array}{c}\text { Apoptotic } \\
\text { Cell } \\
\text { Count }\end{array}$ & $\begin{array}{c}\text { Connective } \\
\text { Tissue }\end{array}$ & $\begin{array}{c}\text { Sinusoidal } \\
\text { Dilatation }\end{array}$ & $\begin{array}{c}\text { Glycogen } \\
\text { Deposition }\end{array}$ & $\begin{array}{c}\text { Young's } \\
\text { Modulus }\end{array}$ & $\begin{array}{c}\text { Fracture } \\
\text { Toughness }\end{array}$ & $\begin{array}{c}\text { Settling } \\
\text { Time }\end{array}$ \\
\hline $\begin{array}{c}\text { Apoptotic } \\
\text { Cell } \\
\text { Count }\end{array}$ & - & 0.84 & SI & -0.48 & 0.51 & 0.68 & 0.69 \\
\hline
\end{tabular}




\begin{tabular}{|c|c|c|c|c|c|c|c|}
\hline $\begin{array}{l}\text { Connective } \\
\text { Tissue }\end{array}$ & $\begin{array}{c}\text { Very } \\
\text { Strong }\end{array}$ & - & SI & -0.66 & 0.74 & 0.80 & 0.83 \\
\hline $\begin{array}{l}\text { Sinusoidal } \\
\text { Dilatation }\end{array}$ & SI & SI & - & -0.53 & SI & SI & SI \\
\hline $\begin{array}{l}\text { Glycogen } \\
\text { Deposition }\end{array}$ & Moderate & Strong & Moderate & - & -0.90 & -0.92 & -0.87 \\
\hline $\begin{array}{l}\text { Young's } \\
\text { Modulus }\end{array}$ & Moderate & Strong & SI & $\begin{array}{c}\text { Very } \\
\text { Strong }\end{array}$ & - & 0.87 & 0.81 \\
\hline $\begin{array}{l}\text { Fracture } \\
\text { Toughness }\end{array}$ & Strong & $\begin{array}{l}\text { Very } \\
\text { Strong }\end{array}$ & SI & $\begin{array}{c}\text { Very } \\
\text { Strong }\end{array}$ & $\begin{array}{c}\text { Very } \\
\text { Strong }\end{array}$ & - & 0.90 \\
\hline $\begin{array}{l}\text { Settling } \\
\text { Time }\end{array}$ & Strong & $\begin{array}{c}\text { Very } \\
\text { Strong }\end{array}$ & SI & $\begin{array}{c}\text { Very } \\
\text { Strong }\end{array}$ & $\begin{array}{c}\text { Very } \\
\text { Strong }\end{array}$ & $\begin{array}{c}\text { Very } \\
\text { Strong }\end{array}$ & - \\
\hline
\end{tabular}

Table 5). A normalized sensitivity measure is defined as the change in mechanical/histological property per change in preservation period.

$$
\text { Sensitivity }=\frac{(\text { property }[k+1]-\text { property }[k]) / \operatorname{property}[k]}{(P T[k+1]-P T[k])} * 100
$$

where, "property[k]" is the $\mathrm{k}^{\text {th }}$ value of a mechanical/histological property measured at “PT[k]”. 


\section{Discussion}

The mechanical properties (stiffness, viscosity, and fracture resistance) of bovine liver increase as a function of preservation period and there is a 'very strong' correlation among them (Table 4). The results of the static indentation experiments performed in this study show that the liver tissue becomes stiffer as it spends more time in the preservation solution. We observed that the tangent elastic modulus of bovine liver varies between $1.6 \mathrm{kPa}(\mathrm{PT}=5 \mathrm{hrs})$ and $33.6 \mathrm{kPa}(\mathrm{PT}=53 \mathrm{hrs})$. Hence, our results suggest that bovine liver preserved in Lactated Ringer solution for $53 \mathrm{hrs}$ becomes almost 21 times stiffer than its state at 5 hrs. All these values are in line with the earlier findings in the literature. Chen et al. (1996) estimated the elastic modulus of bovine liver between $0.4-0.7 \mathrm{kPa}$ using an ultrasound device and between 0.3-1.6 kPa using a mechanical tensile testing device. Ocal et al. (2010) estimated the elastic modulus of fresh bovine liver as $4.1 \mathrm{kPa}$. Liu and Bilston (2000) performed rheological experiments and reported the shear modulus of bovine liver as $0.6 \mathrm{kPa}$. Brosses et al. (2010) examined the material properties of bovine liver using the SSI (Supersonic Shear Imaging) technique and estimated its shear modulus as $3.4 \mathrm{kPa}$. The linear elastic modulus of porcine liver was estimated as $\sim 10 \mathrm{kPa}$ in the earlier studies (Kruse et al. 2000; Ottensmeyer et al. 2001; Samur et al. 2005; Tay et al. 2006). The elastic modulus of human liver was estimated as $20 \mathrm{kPa}$ by Nava et al. (2008) and between 10-20 kPa by Ozcan et al. (2011).

The results of our ramp and hold experiments show that the liver tissue becomes more viscous as it spends more time in the preservation solution, which is in agreement with the results of the earlier studies (Kerdok et al., 2006; Ocal et al., 2010). As the tissue becomes more viscous, it takes longer for it to relax and reach steady state, as shown in Figure 6A. Our 
results suggest that bovine tissue preserved for $53 \mathrm{hrs}$ becomes 1.6 times more viscous than that of 5 hrs (Figure 6B).

The results of the needle insertion experiments show that the fracture toughness of the liver increases up to PT $=29 \mathrm{hrs}$, but no significant change is observed after that. We found that the toughness values vary between $169 \pm 7 \mathrm{~J} / \mathrm{m}^{2}(\mathrm{PT}=5 \mathrm{hrs})$ and $308 \pm 6 \mathrm{~J} / \mathrm{m}^{2}(\mathrm{PT}=53$ hrs). Hence, our results suggest that it is 1.8 times more difficult to cut or tear bovine liver tissue preserved for $53 \mathrm{hrs}$, compared to $5 \mathrm{hrs}$. These results are in good agreement with the earlier findings. Gokgol et al. (2012) estimated the fracture toughness of bovine liver as $164 \pm$ $6 \mathrm{~J} / \mathrm{m}^{2}$. The fracture toughness of porcine liver was estimated to vary between $75.8 \mathrm{~J} / \mathrm{m}^{2}$ and 185.6 J/m $\mathrm{m}^{2}$ in Azar and Hayvard (2008) and between 186.9 and $224.8 \mathrm{~J} / \mathrm{m}^{2}$ in Chanthasopeephan et al. (2006).

In the histological examination, the changes in apoptotic cell count, collagen accumulation, sinusoidal dilatation and glycogen deposition in hepatocytes are investigated as a function of preservation period. Our results show $\sim 4$-folds increase in apoptotic cell count at $\mathrm{PT}=29$ hrs compared to PT $=5 \mathrm{hrs}$, but no significant change is observed after PT $=29 \mathrm{hrs}$. Natori et al. (1999) investigated the apoptosis of sinusoidal endothelial cells during cold preservation of liver. The results showed that the number of apoptotic cells have increased 6folds after $24 \mathrm{hrs}$ of preservation. Toom et al. (1991) investigated the effects of preservation solutions on the morphology of rat liver. They observed a significant morphological damage in liver cells preserved for $42 \mathrm{hrs}$ compared to $18 \mathrm{hrs}$. Apoptosis is also linked to the disease progression in the literature. Malhi et al. (2006) suggested that apoptosis is a prominent factor of chronic liver diseases. It has also been reported that apoptosis stimulates inflammatory and fibrotic changes (Canbay et al. 2004). Calabrese et al. (2000), investigated the apoptotic cell levels in hepatitis $\mathrm{C}$ virus (HCV) infection, and they found that the apoptotic cell index varies between $0.01 \%$ and $0.54 \%$ and the index increases with the level of infection. 
Our results show that the accumulation of fibrous tissue at PT $=29 \mathrm{hrs}$ is $\sim 2.5$ times higher than the value measured at PT $=5$ hrs, but the value at PT $=53 \mathrm{hrs}$ is only 1.1 times higher than the value recorded for PT $=29$ hrs. There is 'very strong' correlation (Table ) between the apoptotic cell count and the accumulation of fibrous tissue since the decrease in blood supply naturally triggers the programmed cell death and this controlled mechanism also involves the cells which produce connective tissue.

Our results show no significant change in sinusoidal dilatation as a function of preservation time. However, Jain et al. (2004) and Puhl et al. (2006) investigated the change in sinusoidal dilatation levels during cold storage and perfusion and observed an increase in sinusoidal dilatation as a function of preservation period due to perfusion damage.

Our results show significant decrease (10-12 folds) in the glycogen level, which has a 'moderate' negative correlation with the apoptotic cell count and a 'strong' negative correlation with the accumulated connective tissue (Table ). The glycogen is made and stored primarily in the liver cells, and functions as the secondary energy storage. This result shows that certain percentage of hepatocytes could not synthesize and store glycogen since the deposited glycogen was consumed for the survival and then the cells underwent to apoptosis. Corps et al. (2009) investigated the cell viability in rat livers with different preservation solutions during cold ischemia. ATP, ADP and AMP degraded in 4 hours and the results showed a significant decrease in the glycogen levels. Nowak et al. (2002) and Zaouali et al. (2010) investigated energy kinetics and glycogen-ATP contents and observed a decrease in glycogen levels as a function of preservation period.

Table shows that there is a strong relation between the mechanical and histological properties of the bovine liver. The mechanical properties (stiffness, viscosity, and fracture resistance) are strongly correlated with apoptotic cell count (positive), very strongly with the 
connective tissue (positive) and the glycogen level (negative), and not correlated at all to the sinusoidal dilation. These results are also in agreement with the results of the earlier studies, which are limited in number. The correlation between the fibrous tissue and liver stiffness has been already reported (Sandrin et al., 2003, Ziol et al., 2005, Manduca et al., 2001, Huwart et al. 2006, Mazza et al., 2007, Ozcan et al., 2011). Mori et al. (2011) investigated the correlation between liver stiffness and collagen deposition levels with patients who have nonalcoholic fatty liver disease. They observed that not only the increase in the collagen level, but also the presence of myofibroblasts triggers the chronic liver diseases. Leal-Egaña et al. (2012) investigated the effect of fibrous structure on the spread of liver cancer, and the mechanical property of liver. They suggest that the progression of liver cancer can be prevented by tuning the stiffness of the liver. Lake et al. (2012) investigated the effect of the initial collagen alignment on the mechanical properties of soft tissues. The results showed that different initial alignments do not directly affect the strain-dependent elastic response, but have an influence on the time-dependent relaxation response.

Investigating the relation between mechanical and histological properties not only provides insight into liver damage during disease progression but also during liver preservation for transplantation. During the liver transplantation, the donor and the recipient are mostly in different locations, so the preservation conditions and the transportation duration are both very important. Preservation solutions are designed to inhibit the negative effects of ischemia and to maintain the tissue viability. However, even the most effective solutions can preserve the organ up to certain duration only, though there is no consensus among the physicians on how long this period should be. In this study, we investigated the change in material and histological properties of bovine liver during cold storage. The sensitivity analysis showed that the largest changes in mechanical and histological properties occur between 11-17 hrs. Although the largest change in liver stiffness was observed after $17 \mathrm{hrs}$ of 
preservation, the largest changes in viscosity and fracture toughness occurred after $11 \mathrm{hrs}$ of preservation. The largest change in apoptotic cell count occurred after $11 \mathrm{hrs,}$, and for collagen accumulation and glycogen deposition, the largest changes were observed after the first 17 hrs.

\section{Conclusion}

In order to better understand the damage occurring in liver tissue during disease progression and preservation, the relation between the mechanical and histological properties of liver must be investigated in depth. However, the number of studies in the literature investigating the relationship between the mechanical and histological properties of liver is very limited. Most of the earlier studies in this area have focused on the measurement of one mechanical property (elastic modulus) at a certain frequency, and then finding its correlation with semi-quantitative histological scores. We suggest that the liver damage during disease progression (or during liver preservation) can only be understood truly if the relation between the states of mechanical and histological properties is investigated as a function of "time" as it is done in dynamical systems theory to investigate the behavior of complex systems.

Our study, in addition to investigating the mechanical and histological properties of liver tissue and the correlations between them, also provides insight into how long the liver should be preserved in a Lactated Ringer solution. With the insight gained in this study, we plan to further investigate the effect of commonly used preservation solutions in liver transplantation (University of Wisconsin and HTK) on the mechanical and histological properties of the liver harvested from a donor. Additionally, we plan to examine liver samples under an electron microscope. Through this examination, more insight can be gained about the changes occurring at molecular level in intracellular matrix (ICM). 


\section{References}

Azar, T., Hayward, T., 2008. Estimation of the fracture toughness of soft tissue from needle insertion. Proceedings of the 4th international symposium on biomedical simulations (ISBMS), 166-175.

Brosses, E.S., Gennison, J.L., Pernot, M., Fink, M., Tanter, M., 2010. Temperature dependence of the shear modulus of soft tissues assessed by ultrasound. Phys. Med. Biol. 55, 1701-1718.

Calabrese, F., Pontisso, P., Pettenazzo, E., Benvegnu, L., Vario, A., Chemello, L., Alberti, A., Valente, M., 2000. Liver Cell Apoptosis in Chronic Hepatitis C Correlates With Histological But Not Biochemical Activity or Serum HCV-RNA Levels. Hepatology 31, 1153-1159.

Canbay, A., Freidman, S., Gores, G.J., 2004. Apoptosis: The nexus of liver injury and fibrosis. Hepatology 39, 273-278.

Chanthasopeephan, T., Desai, J.P., Lau, A.C.W., 2006. Determining fracture characteristics in scalpel cutting of soft tissue. IEEE/RAS-EMBS conference on biomedical robotics and biomechatronics, 899-904.

Chen, E.J., Novakofski, J., Jenkins, W.K., O’Brien, W.D., 1996. Young's modulus measurements of soft tissues with application to elasticity imaging. IEEE Transactions on Ultrasonics Ferroelectrics and Frequency Control 43, 191-194.

Cui, D.X., Yin, J.Q., Xu, W.X., Chai, F., Liu, B.L., Zhang, X.B., 2010. Effects of different bile duct flush solutions on biliary tract preservation injury of donated livers for transplantation. Trans. Proc. 42, 1576-1581. 
Corps, C.L., Shires, M., Crellin, D., Smolenski, R., Potts, D., Pratt, J., Lodge, J.P.A., 2009. Influence on energy kinetics and histology of different preservation solutions seen during cold ischemia in the liver. Trans. Proceed. 41, 4088-4093.

Gao, Z., Desai, J., 2010. Estimating zero-strain states of very soft tissue under gravity loading using digital image correlation. Med. Image Anal. 14, 126-137.

Ghadiali, S.N., Banks, J., Swarts, J.D., 2004. Finite element analysis of active Eustachian tube function. J. App. Physiology 97, 648-654.

Gokgol, C., Basdogan, C., Canadinc, D., 2012. Estimation of fracture toughness of liver tissue: experiments and validation. Med. Eng. and Phys. 34, 882-891.

Guibert, E.E., Petrenko, A.Y., Balaban, C.L., Somov, A.Y., Rodriguez, J.V., Fuller, B.J., 2011. Organ preservation: current concepts and new strategies for the next decade. Transfus. Med. Hemother. 38, 125-142.

Hewitt, J.D., Harrelson, J.M., Dailiana, Z., Fink, Guilak F., 2005. The effect of intermittent pneumatic compression on fracture healing. J. Ortho. Trauma. 19, 371-376.

Hu, T., Lau, A., Desai, J., 2008. Instrumentation for testing soft tissue undergoing large deformation: ex vivo and in vivo studies. J. Med. Devices. 2, 041001-1-041001-6.

Huwart, L., Peeters, F., Sinkus, R., Annet, L., Salameh, N., ter Beek, L.C., Horsmans, Y., Van Beers, B.E., 2006. Liver fibrosis: non-invasive assessment with MR elastography. NMR in Biomed. 19, 173-179.

Jain, S., Xu, H., Duncan, H., Jones Jr., J.W., Zhang, J.X., Clemens, M.G., Lee, C.Y., 2004. Ex-vivo study of flow dynamics and endothelial cell structure during extended hypothermic machine perfusion preservation of livers. Cryobiology 48, 322-332. 
Kerdok, A.E., Ottensmeyer, M.P., Howe, R.D., 2006. Effects of perfusion on the viscoelastic characteristics of liver. J. Biomech. 39, 2221-2231.

Knol, J.A., Marn, C.S., Francis, I.R., Rubin, J.M., Bromberg, J., Chang, A.E., 1993. Comparison of dynamic infusion and delayed computed- tomography, intraoperative ultrasound, and palpation in the diagnosis of liver metastases. American J. Surg. 165, 81-88.

Kruse, S.A., Smith, J.A., Lawrence, A.J., Dresner, M.A., Manduca, A., Greenleaf, J.F., Ehman, R.L., 2000. Tissue characterization using magnetic resonance elastography: preliminary results. Phys. Med. Biol. 45, 1579-1590.

Lake, S. P., Barocas, V. H., 2012. Mechanics and kinematics of soft tissue under indentation are determined by the degree of initial collagen fiber alignment. Journal of the Mechanical Behavior of Biomedical Materials 13, 25-35.

Leal-Egaña, A., Fritsch, A., Heidebrecht, F., Díaz-Cuenca, A., Nowicki, M., Bader, A., Käs, J., 2012. Tuning liver stiffness against tumours: An in vitro study using entrapped cells in tumour-like microcapsules. Journal of the Mechanical Behavior of Biomedical Materials 9, $113-121$.

Li, Z.Y., Howarth, S., Trivedi, R.A., U-King-Im, J.M., Graves, M.J., Brown, A., Wang, L.Q., Gillard, J.H., 2006. Stress analysis of carotid plaque rupture based on in vivo high resolution MRI. J. Biomech. 39, 2611-2622.

Liu, Z., Bilston, L., 2000. On the viscoelastic character of liver tissue: experiments and modeling of the linear behavior. Biorheology 37, 191-201.

Malhi, H., Gores, G. J., Lemasters, J. J., 2006. Apoptosis and necrosis in the liver: a tale of two deaths? Hepatology 43, S31-S44. 
Manduca, A., Oliphant, T.E., Dresner, M.A., Mahowald, J.L., Kruse, S.A., Amromin, E., Felmlee, J.P., Greenleaf, J.F., Ehman, R.L., 2001. Magnetic resonance elastography: noninvasive mapping of tissue elasticity. Med. Image Anal. 5, 237-254.

Mazza, E., Nava, A., Hahnloser, D., Jochum, W., Bajka, M., 2007. The mechanical response of human liver and its relation to histology: an in vivo study. Med. Image Anal. 11, 663-672.

Moreira, R.K., 2007. Hepatic stellate cells and fibrosis. Archives of Pathology \& Laboratory Med. 131, 1728-1734.

Mori, M., Fujii, H., Ogawa, T., Kobayashi, S., Iwai, S., Morikawa, H., Enomoto, M., Tamori, A., Sawada, A., Takeda, S., Kawada, N., 2011. Close correlation of liver stiffness with collagen deposition and presence of myofibroblasts in non-alcoholic fatty liver disease. Hepatology Res. 41(9), 897-903.

Natori, S., Selzner, M., Valentino, K.L., Fritz, L.C., Srinivasan, A., Clavien, P.A., Gores, G.J., 1999. Apoptosis of sinusoidal endothelial cells occurs during liver preservation injury by a caspase-dependent mechanism. Transplant. 68, 89-96.

Nava, A., Mazza, E., Furrer, M., Villiger, P., Reinhart, W.H., 2008. In vivo mechanical characterization of human liver. Med. Image Anal. 12, 203-216.

Nowak, G., Ungerstedt, J., Wernerman, J., Ungerstedt, U., Ericzon, B.G., 2002. Metabolic changes in the liver graft monitored continuously with microdialysis during liver transplantation in a pig model. Liver Transpl. 8, 424-432.

Ocal, S., Ozcan, M.U., Basdogan, I., Basdogan, C., 2010. Effect of preservation period on the viscoelastic material properties of soft tissues with implications for liver transplantation. J. Biomech. Eng. 132, 10: 101007. 
Ottensmeyer, M.P., 2001. Minimally invasive instrument for in vivo measurement of solid organ mechanical impedance. Ph.D. Thesis, Dep. Mech. Eng., MIT.

Ozcan M. U., Ocal S., Basdogan C., Dogusoy G. Tokat Y., 2011. Characterization of frequency-dependent material properties of human liver and its pathologies using an impact hammer. Med. Image Anal. 15, 45-52.

Puhl, G., Olschewski, P., Schöning, W., Hunold, G., Liesaus, H.G., Winkler, R., Neumann, U.P., Schubert, T.E.O., Schmitz, V., Neuhaus, P., 2006. Low viscosity histidine-tryptophanketoglutarate graft flush improves subsequent extended cold storage in university of wisconsin solution in an extracorporeal rat liver perfusion and rat liver transplantation model. Liver Transpl. 12, 1841-1849.

Rockey, Don.C., Caldwell, S.H., Goodman, Z.D., Nelson, R.C., Smith, A.D., 2009. Liver Biopsy. Hepatology. 49, 1017-1044.

Rosen, J., Brown, J.D., De, S., Sinanan, M., Hannaford, B., 2008. Biomechanical properties of abdominal organs in vivo and postmortem under compression loads. J. Biomech. Eng. 130, 021020-1-021020-16.

Samur, E., Sedef, M., Basdogan, C., Avtan, L., Duzgun, O., 2005. A robotic indenter for minimally invasive characterization of soft tissues. Proceedings of the International Conference on Computer Assisted Radiology and Surgery, 1281, 713-718.

Samur, E., Sedef, M., Basdogan, C., Avtan, L., Duzgun, O., 2007. A robotic indenter for minimally invasive measurement and characterization of soft tissue behavior. Med. Image Anal. 11, 361-373.

Sandrin, L., Fourquet, B., Hasquenoph, J.M., Yon, S., Fournier, C., Mal, F., Christidis, C., Ziol, M., Poulet, B., Kazemi, F., Beaugrand, M., Palau, R., 2003. Transient elastography: a 
new noninvasive method for assessment of hepatic fibrosis. Ultrasound Med. Biol. 29, 17051713.

Shiha, G., Zalata, K., 2011. Ishak versus METAVIR: Terminology, Convertibility and Correlation with Laboratory Changes in Chronic Hepatitis C. Liver Biopsy, 10, 155-170.

Standish, R.A., Cholongitas, E., Dhillon, A., Burroughs, A.K., Dhillon, A.P., 2006. An appraisal of the histopathological assessment of liver fibrosis. Gut 55, 569-78.

Tay, B.K., Kim, J., Srinivasan, M.A., 2006. In vivo mechanical behavior of intra-abdominal organs. IEEE Trans. Biomed. Eng., 53, 2129-2138.

Toom, R.D., Jong, M.D., Krenning, E.P., Hoek, H.J.V.D, Kate, F.J.W.T, Henneman, G., Terpstra, O.T., 1991. Euro-collins solution versus uw-solution for long-term liver preservation in the isolated rat-liver perfusion model. HPB Surgery 4, 313-320.

Weaver, B.T., Haut, R.C., 2005. Enforced exercise after blunt trauma significantly affects biomechanical and histological changes in rabbit retro-patellar cartilage. J. Biomech. 38, $1177-1183$.

Zaouali, M., Padrissa-Altés, S., Ben Mosbah, I., Alfany-Fernandez, I., Massip-Salcedo, M., Casillas-Ramirez, A., Bintanel-Morcillo, M., Boillot, O., Serafin, A., Rimola, A., Rodés, J., Roselló-Catafau, J. \& Peralta, C., 2010. Improved rat steatotic and nonsteatotic liver preservation by the addition of epidermal growth factor and insulin-like growth factor-I to University of Wisconsin solution. Liver Transpl. 16, 1098-1111.

Zeisberg, M., Yang, C., Martino, M., Duncan, M.B., Rieder, F., Tanjore, H., Kalluri, R., 2007. Fibroblasts derive from hepatocytes in liver fibrosis via epithelial to mesenchymal transition. J. Biol. Chem. 282, 23337-23347. 
Ziol, M., Handra-Luca, A., Kettaneh, A., Christidis, C., Mal, F., Kazemi, F., de Ledinghen, V., Marcellin, P., Dhumeaux, D., Trinchet, J.C., Beaugrand, M., 2005. Noninvasive assessment of liver fibrosis by measurement of stiffness in patients with chronic hepatitis $\mathrm{C}$. Hepatology 41(1), 48-54. 

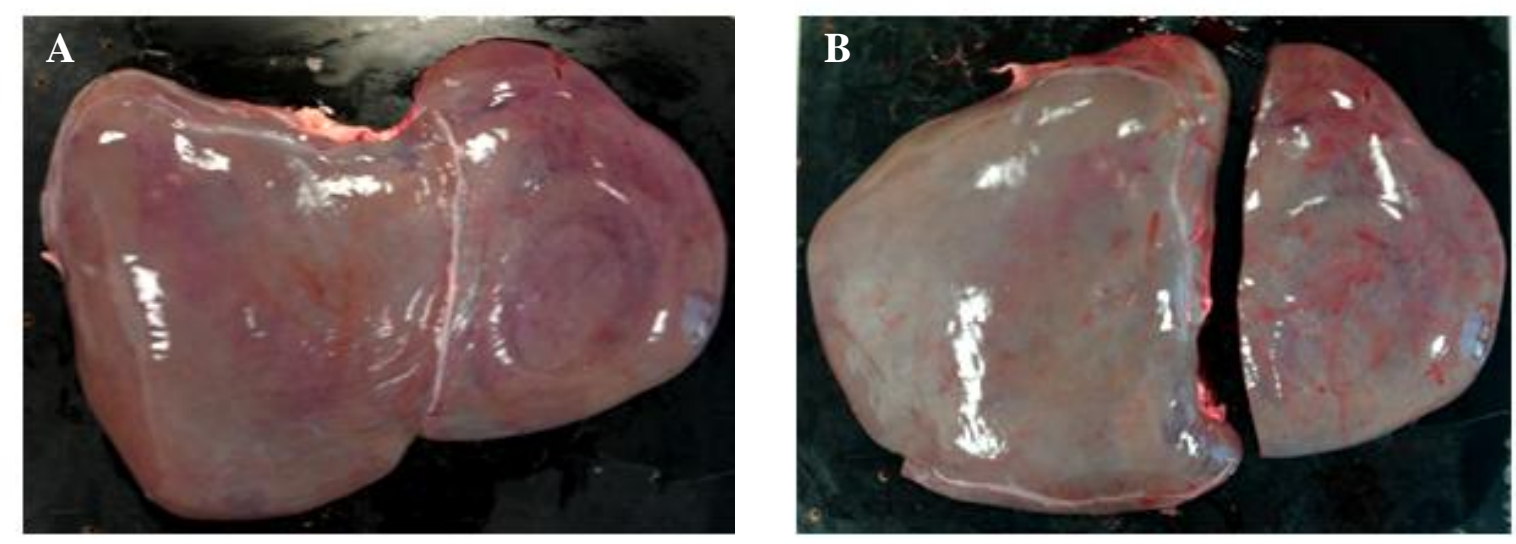

Figure 1. (A) The whole bovine liver and (B) its separated right lobe. 

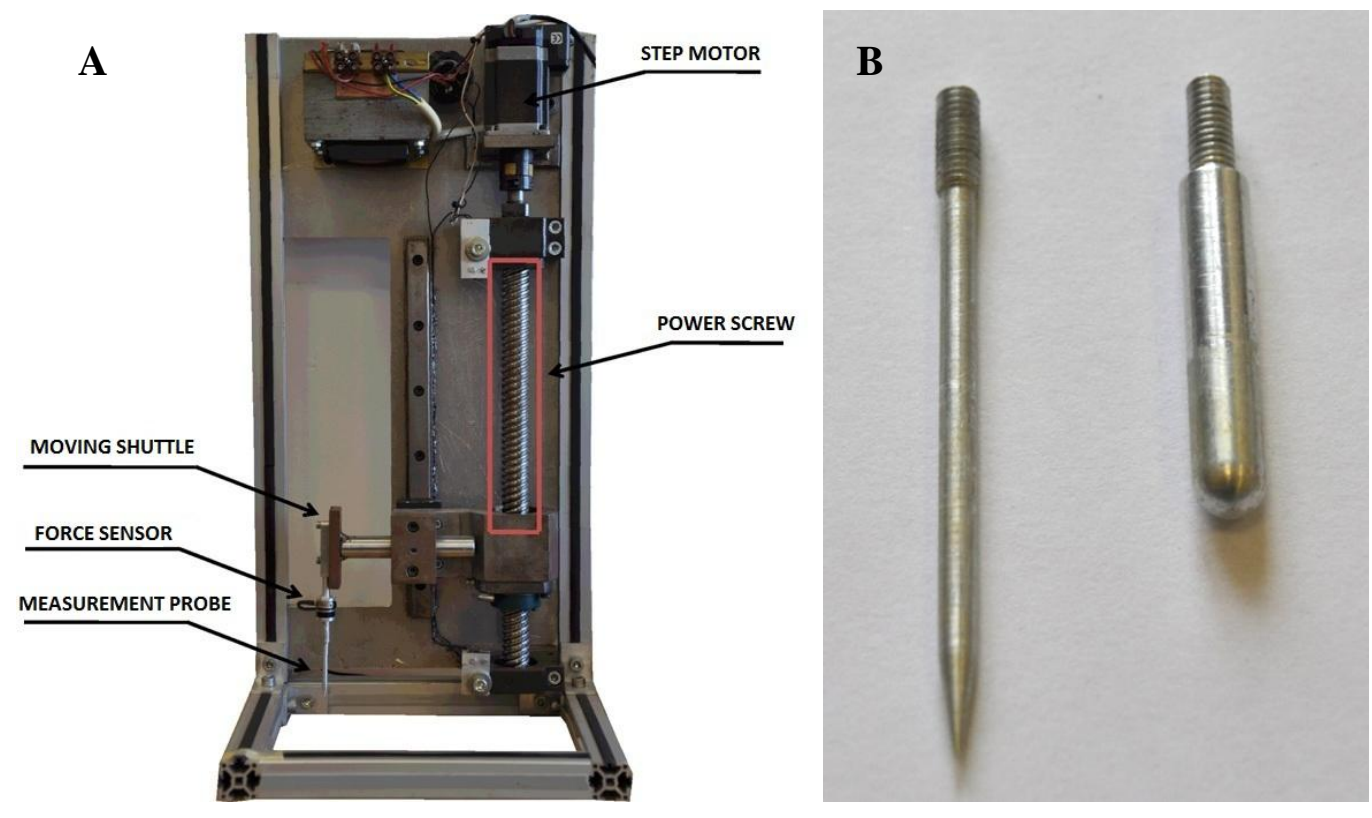

Figure 2. (A) Our set-up for conducting mechanical characterization experiments. (B) The needle (diameter $=3 \mathrm{~mm}$ ) and the cylindrical probe (diameter $=6 \mathrm{~mm}$ ) used for the mechanical characterization experiments. 


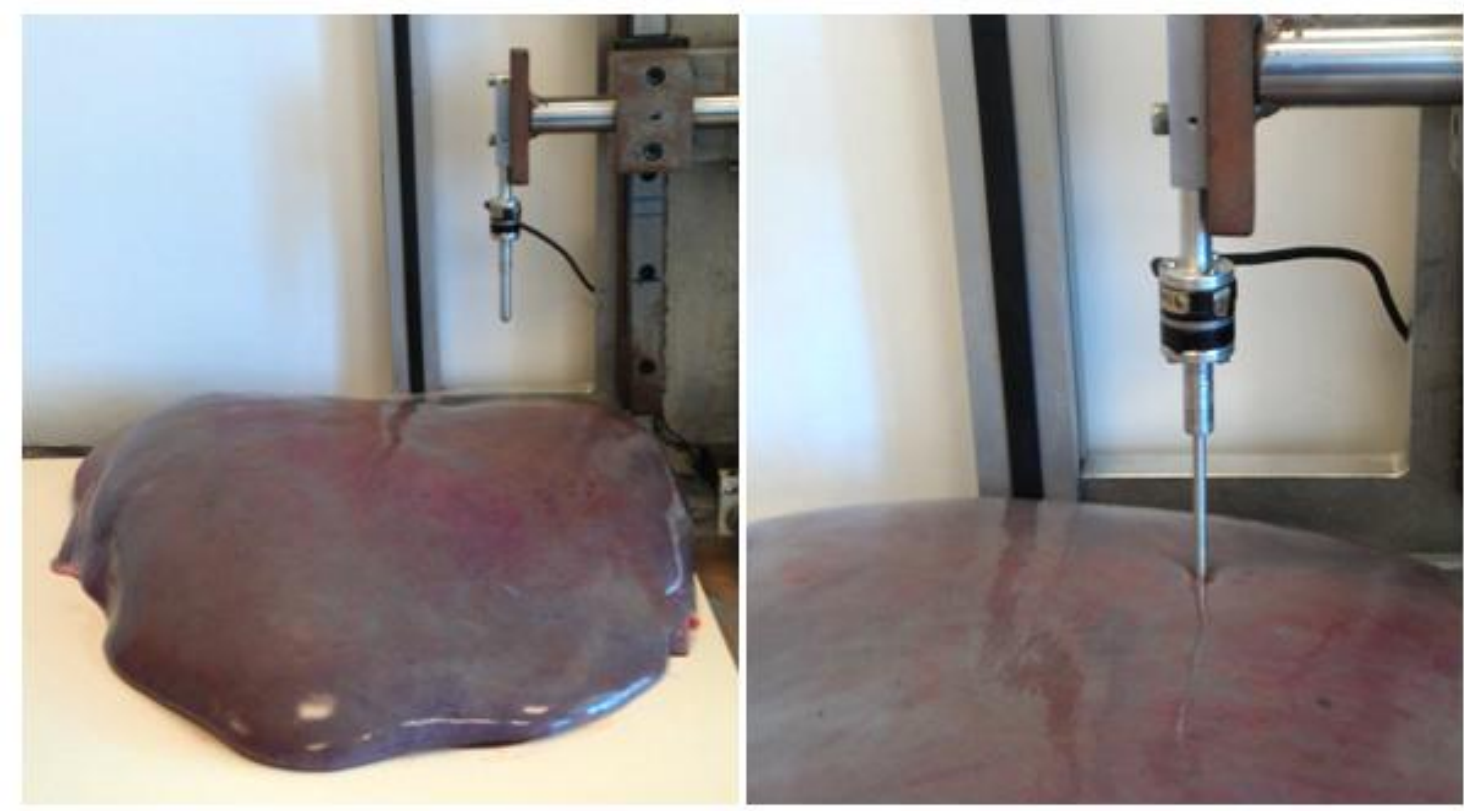

Figure 3. Scenes from the compression experiments performed on one of the livers tested in our study. 


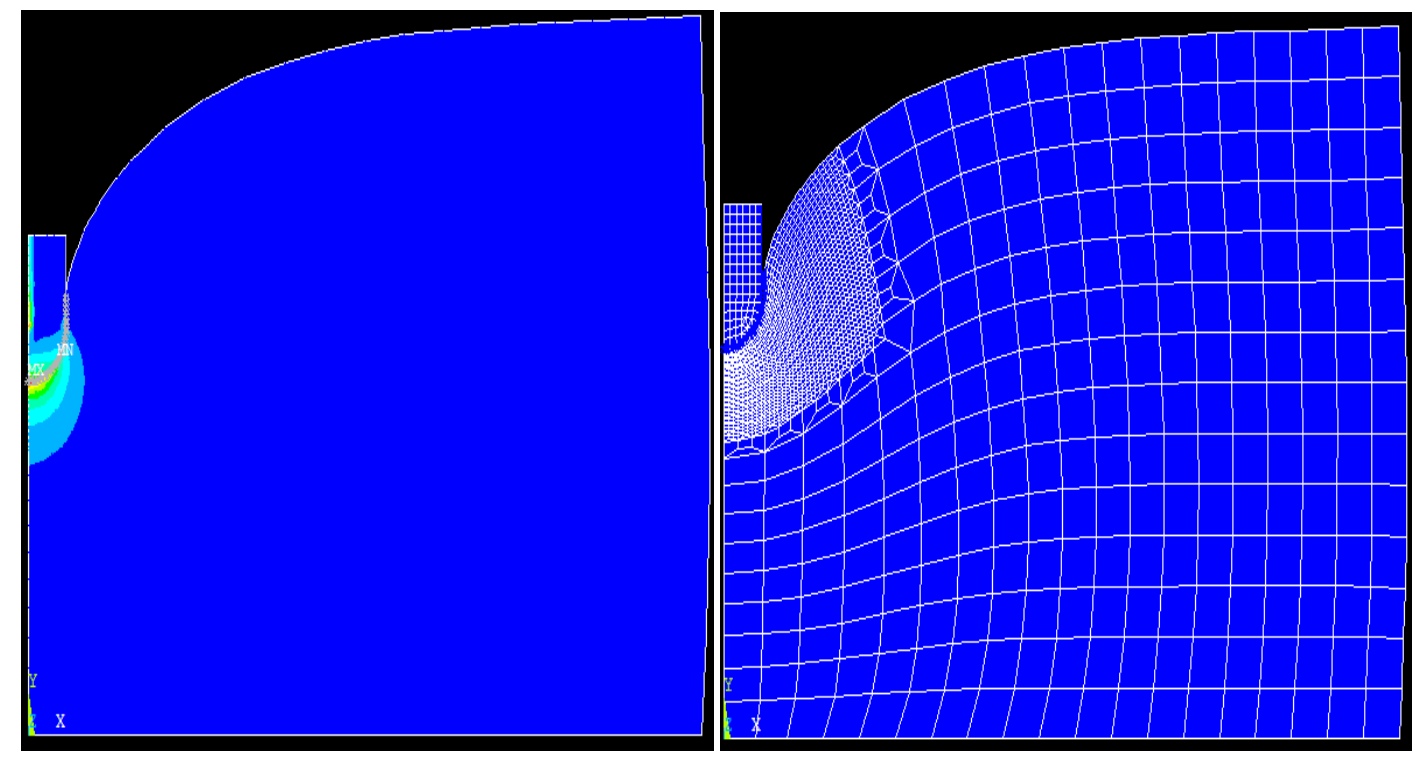

Figure 4. A finite element model of bovine liver deformed with a cylindrical probe. 

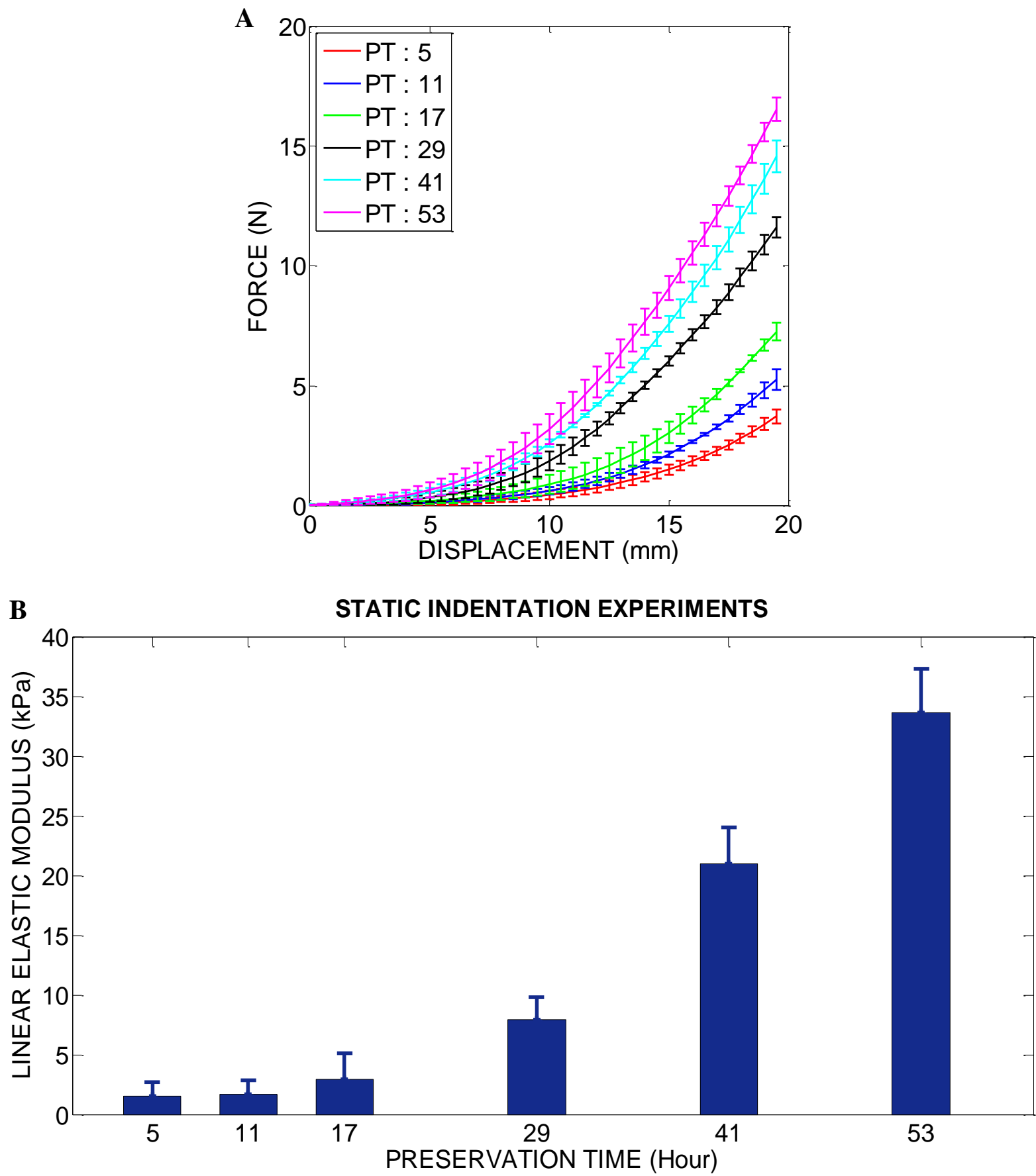

Figure 5. (A) The force response of bovine liver (average of 3 animals) as a function of compression depth for different preservation times. (B) The linear elastic modulus of bovine liver (average of 3 animals) as a function of preservation time. 


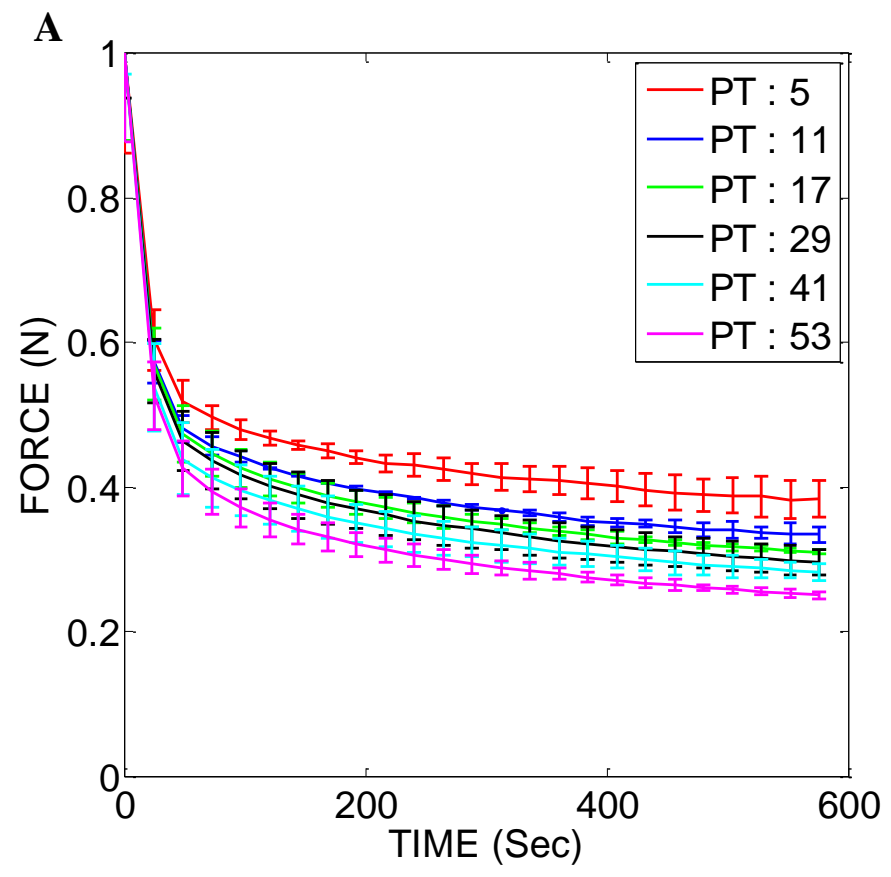

B

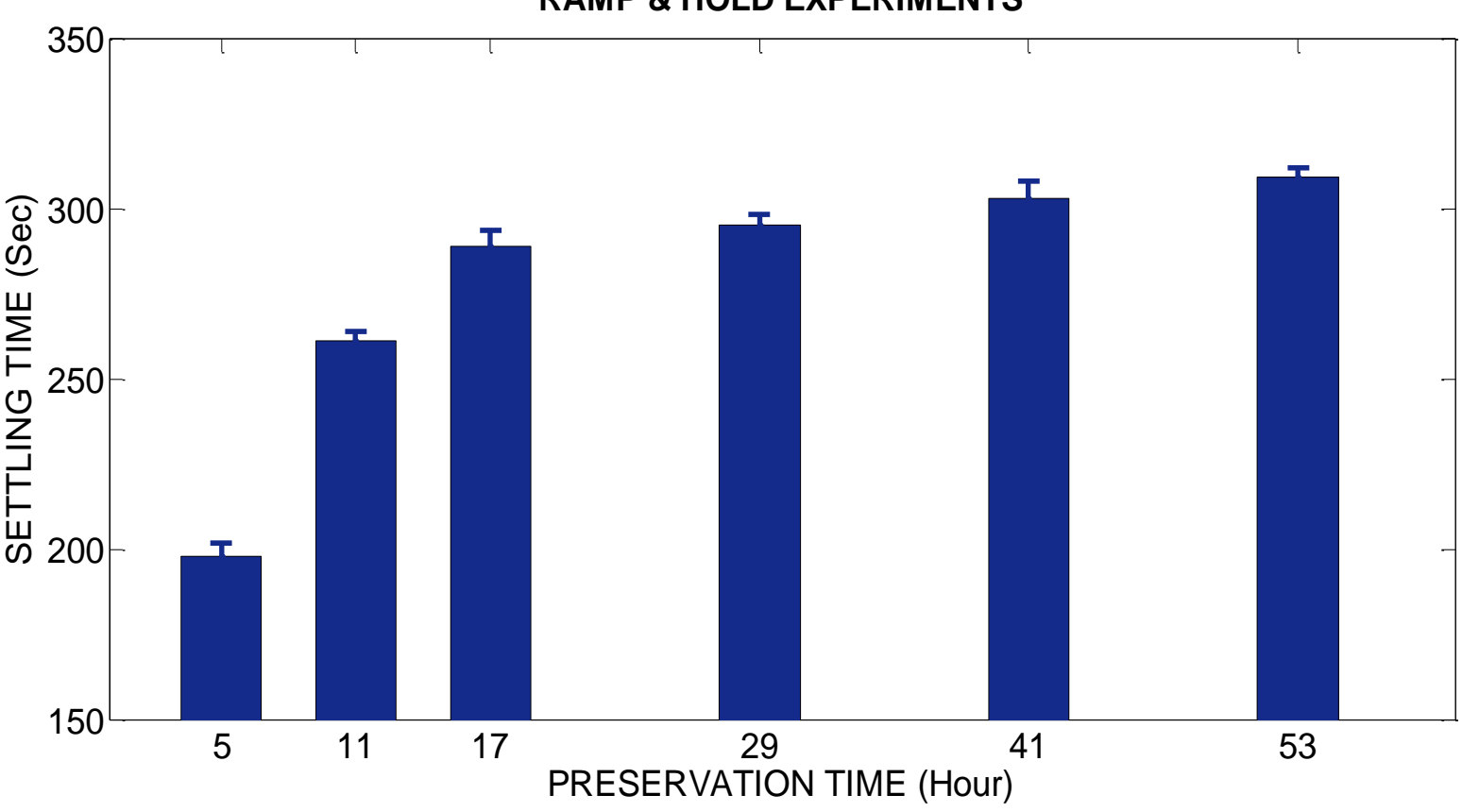

Figure 6. (A) The normalized force relaxation response of bovine liver (average of 3 animals) for different preservation times. (B) The settling time of the relaxation response for different preservation times. 

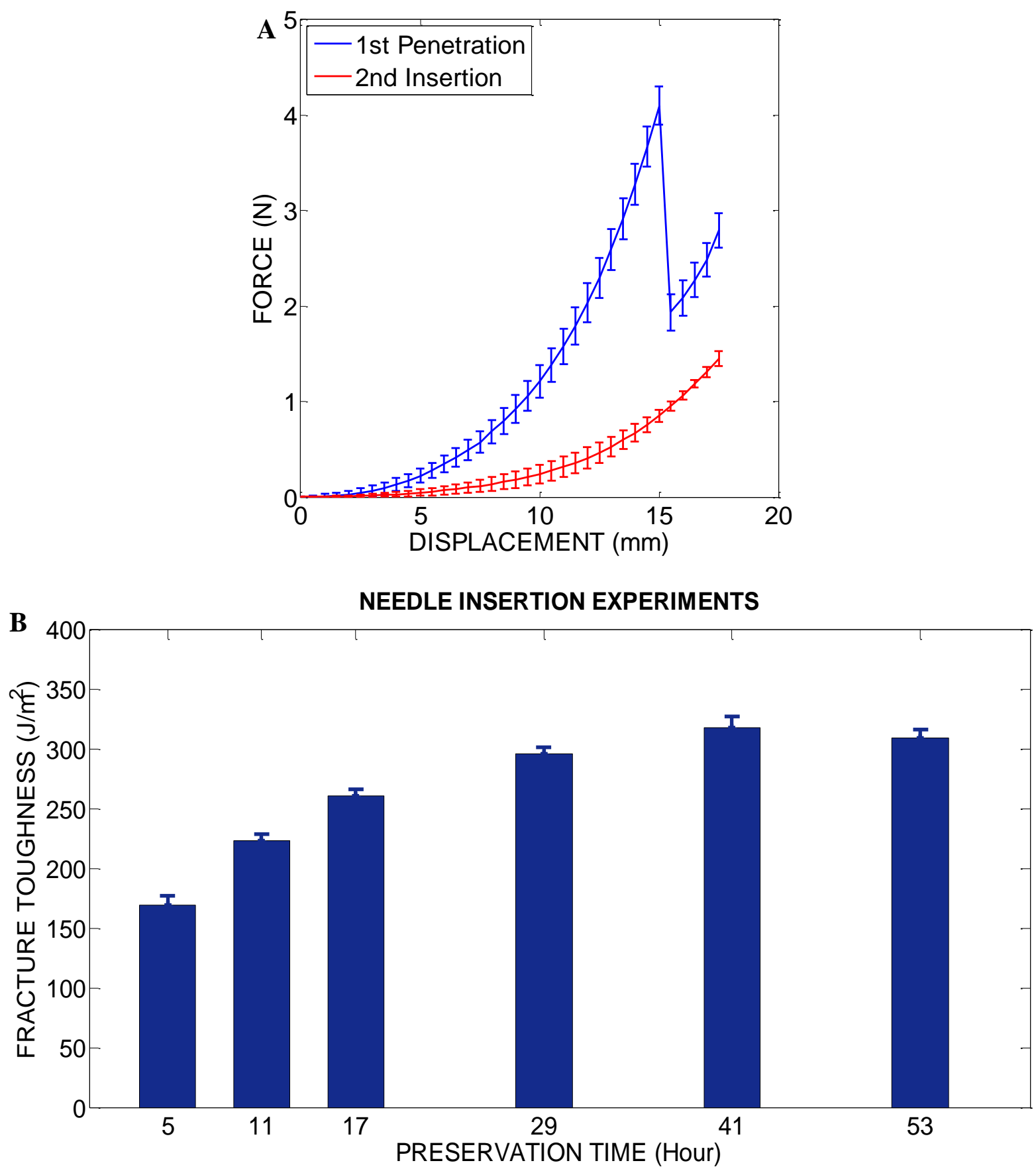

Figure 7. (A) The force displacement responses of the bovine liver of Animal \#1 during the first and second needle insertions. (B) The change in fracture toughness of bovine liver (average of 3 animals) as a function of preservation time. 

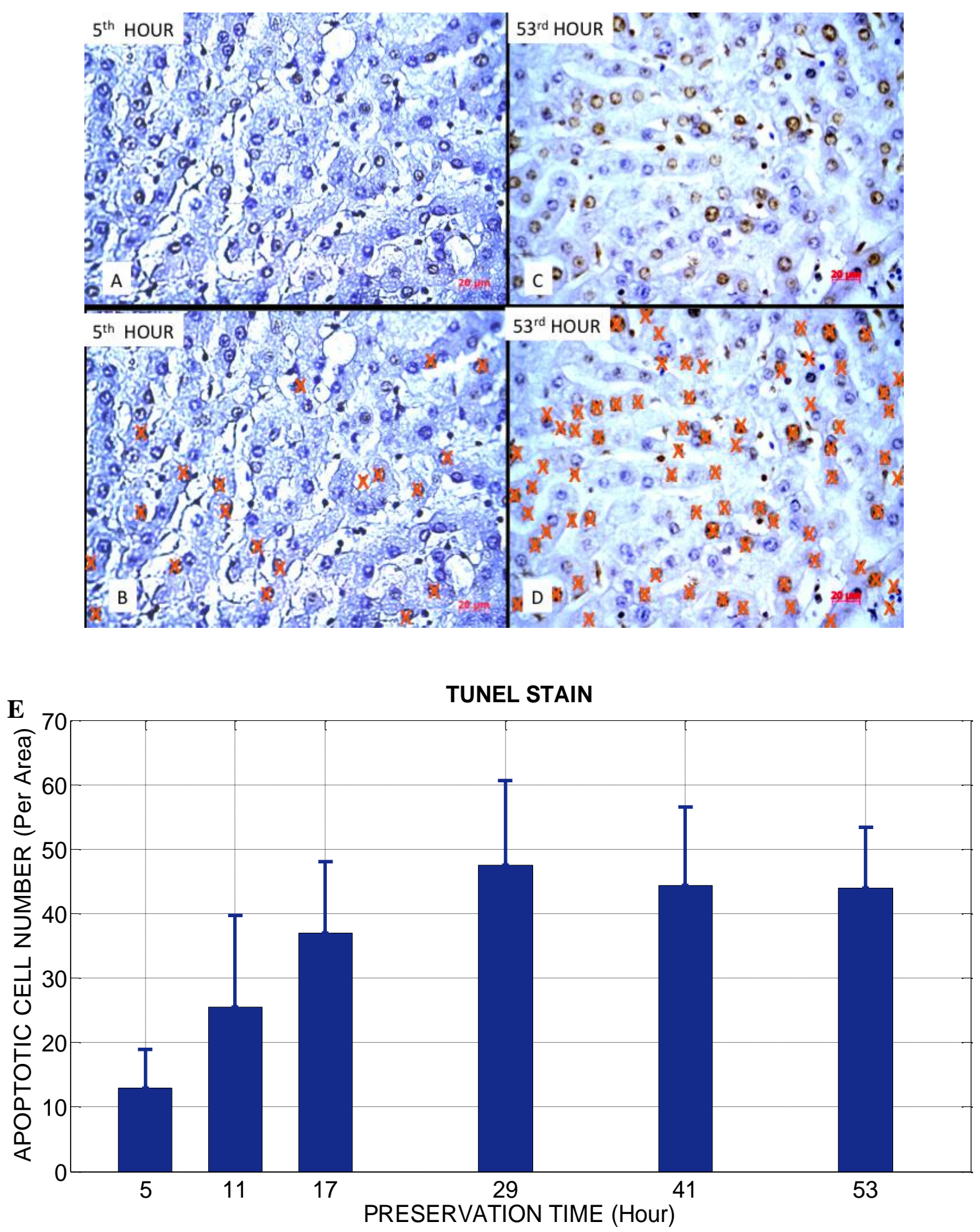

Figure 8. (A, C) The exemplar images of the sections labeled with TUNEL technique and preserved for PT $=5 \mathrm{hrs}$ and $\mathrm{PT}=53 \mathrm{hrs}$. The dark blue stained nuclei shows the healthy cells while the brown/dark brown stained nuclei shows the cells undergoing apoptosis. (B, D) These cells were marked on the micrographs with a cross sign first and then counted. (E) The change in the apoptotic cell count (average of 3 animals) as a function of preservation time. 

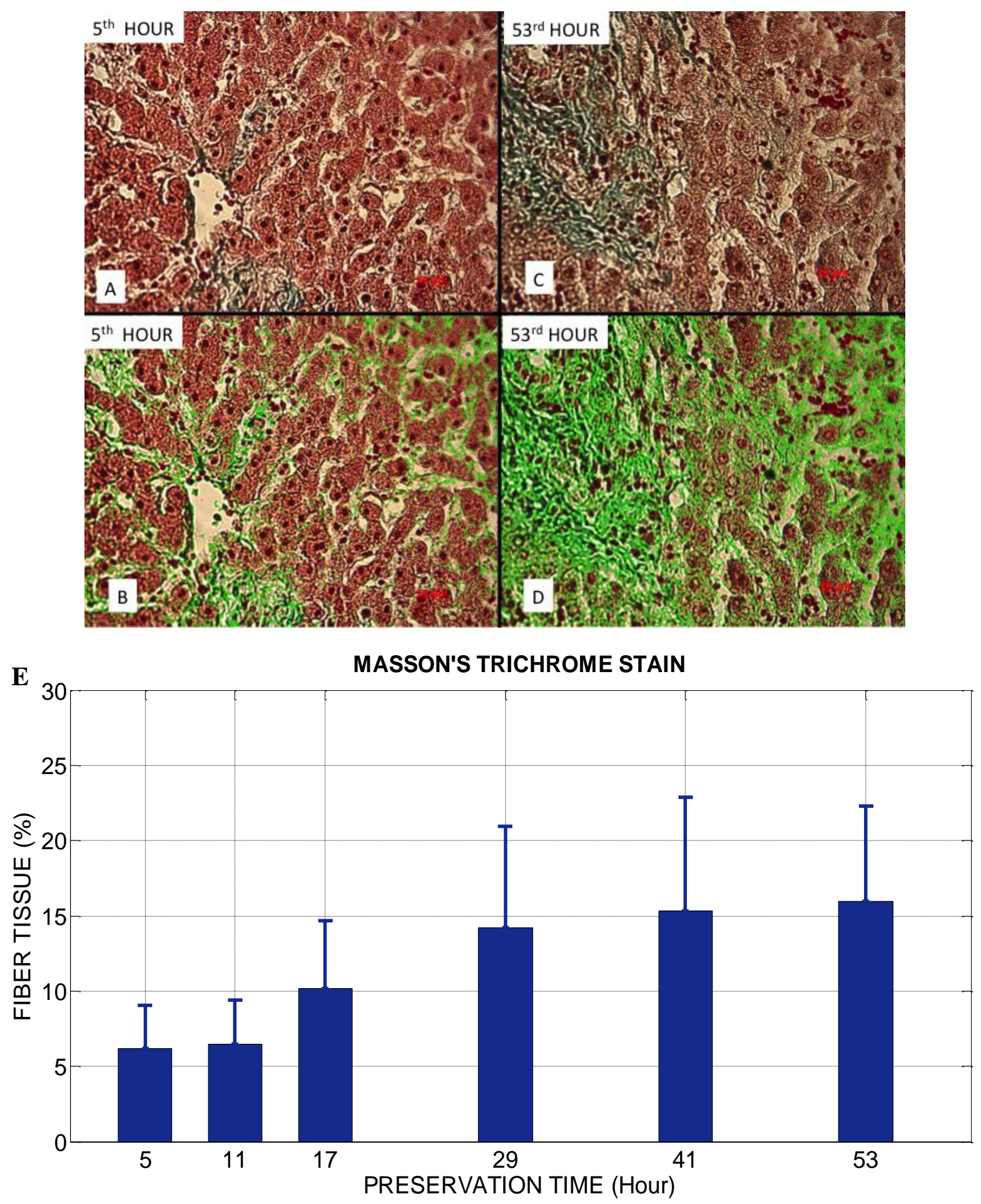

Figure 9. (A, C) The exemplar images of the sections treated by the Masson`s trichrome stain and preserved for PT $=5 \mathrm{hrs}$ and PT $=53 \mathrm{hrs}$. (B, D) The image analysis software measures the areas of green colored regions (E) The change in the connective tissue (average of 3 animals) as a function of preservation time. 


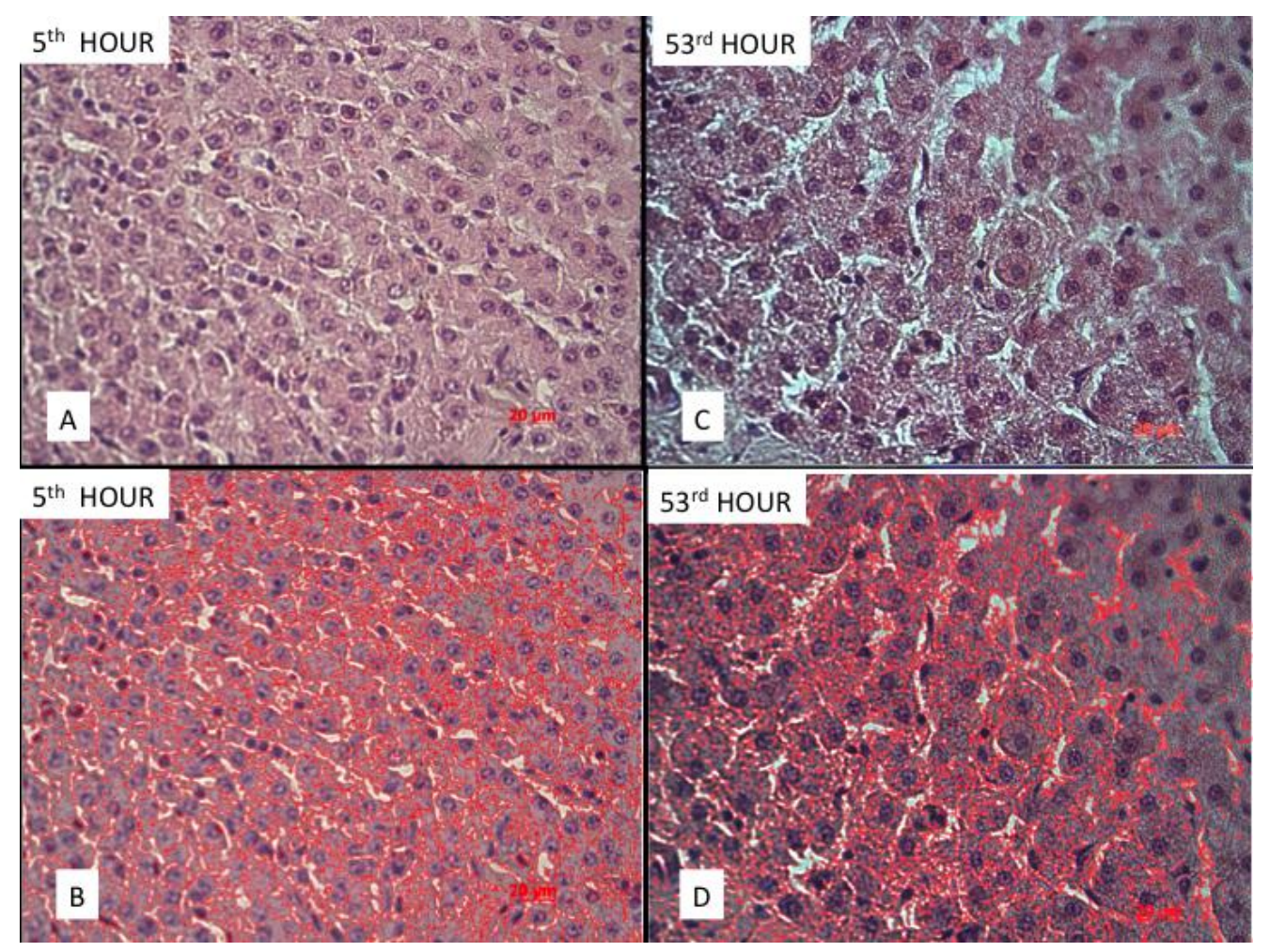

HEMATOXYLIN AND EOSIN STAIN

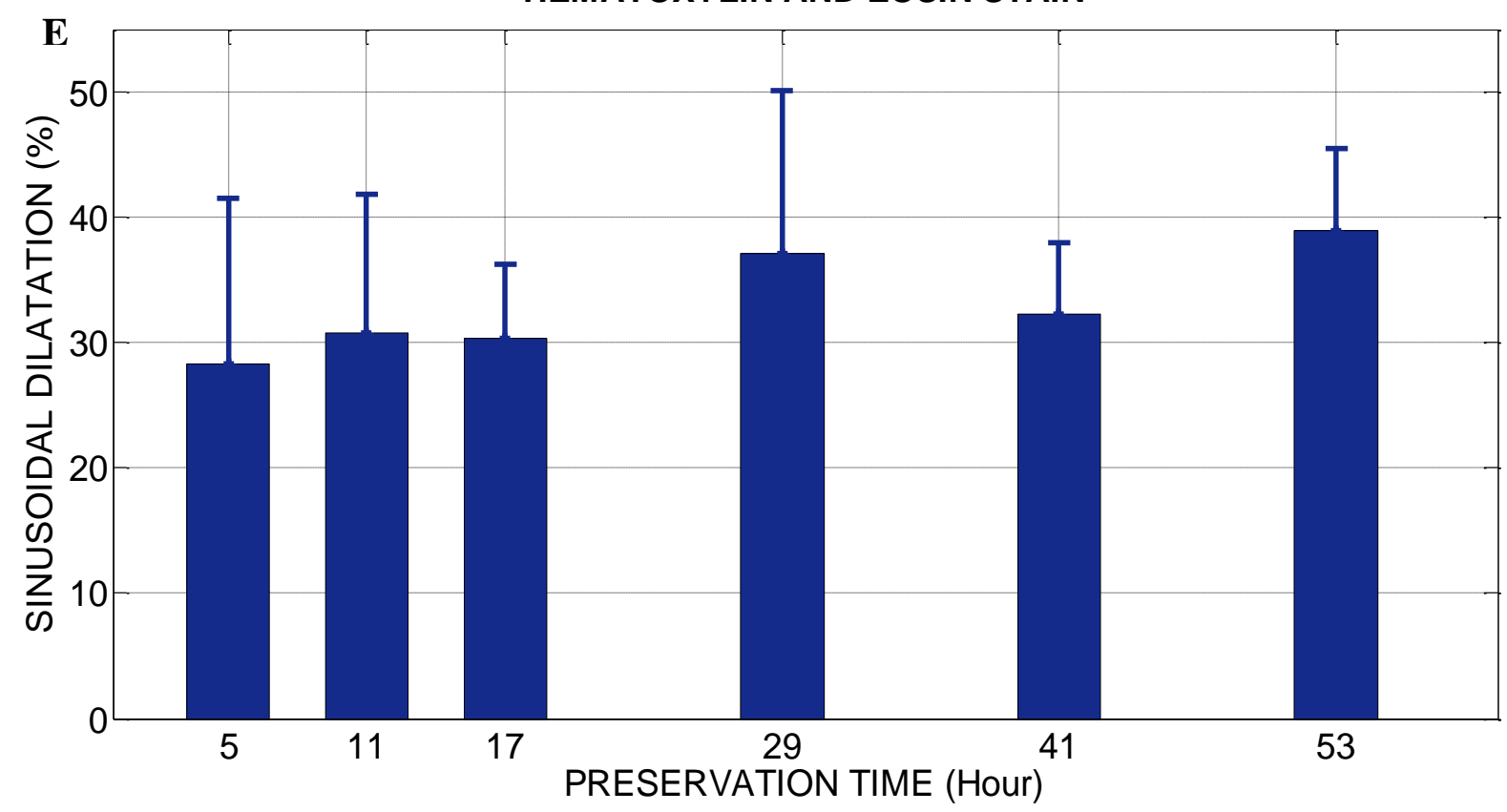

Figure 10. (A, C) The microphotographs show the sections stained with the Hematoxylene and Eosin and preserved for PT $=5 \mathrm{hrs}$ and PT $=53 \mathrm{hrs}$. (B, D) The marked areas show the dilated sinusoids. (E) The change in the sinusoidal dilatation (average of 3 animals) as a function of preservation time. 


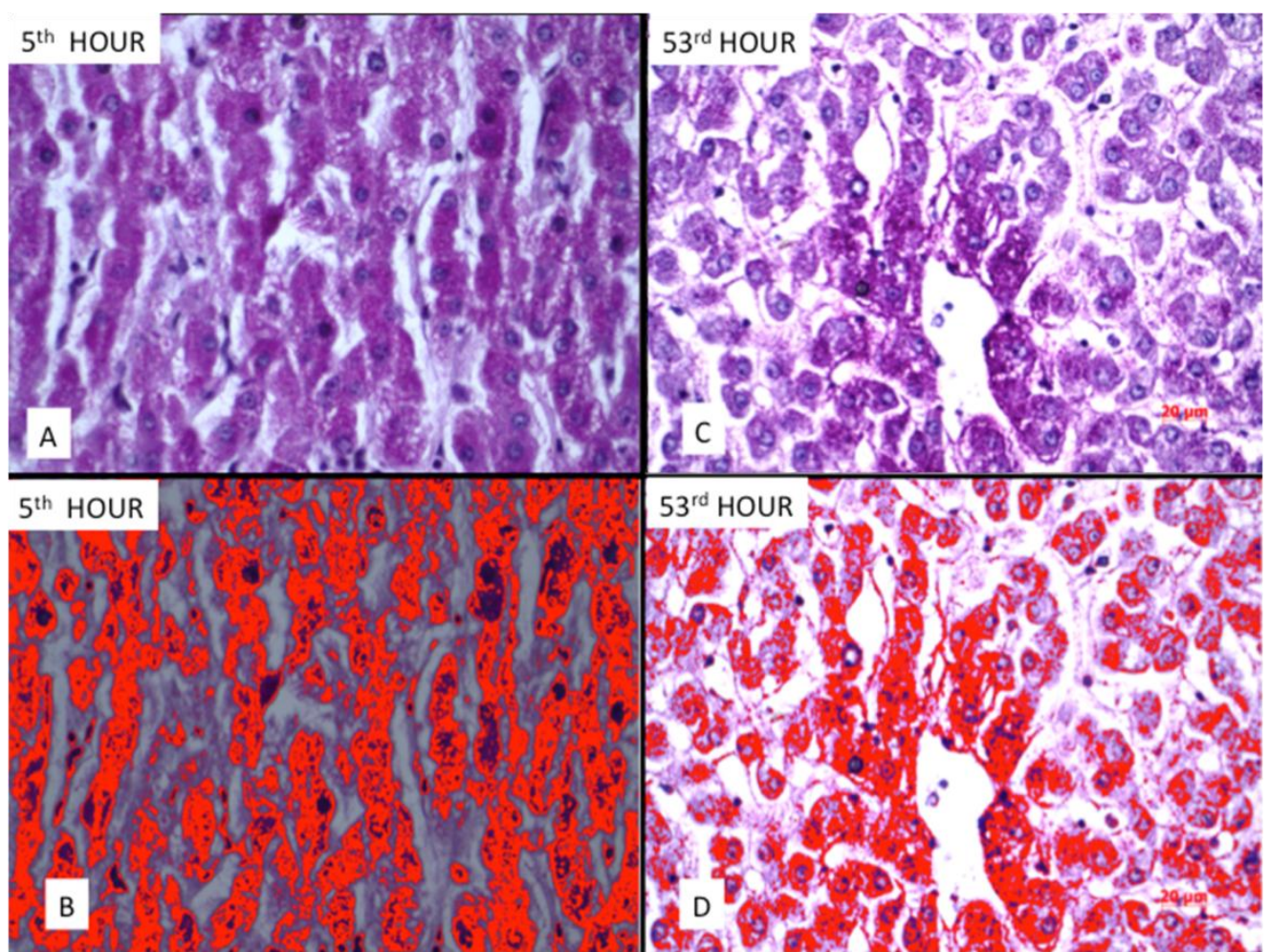

PERIODIC ACID-SCHIFF STAIN

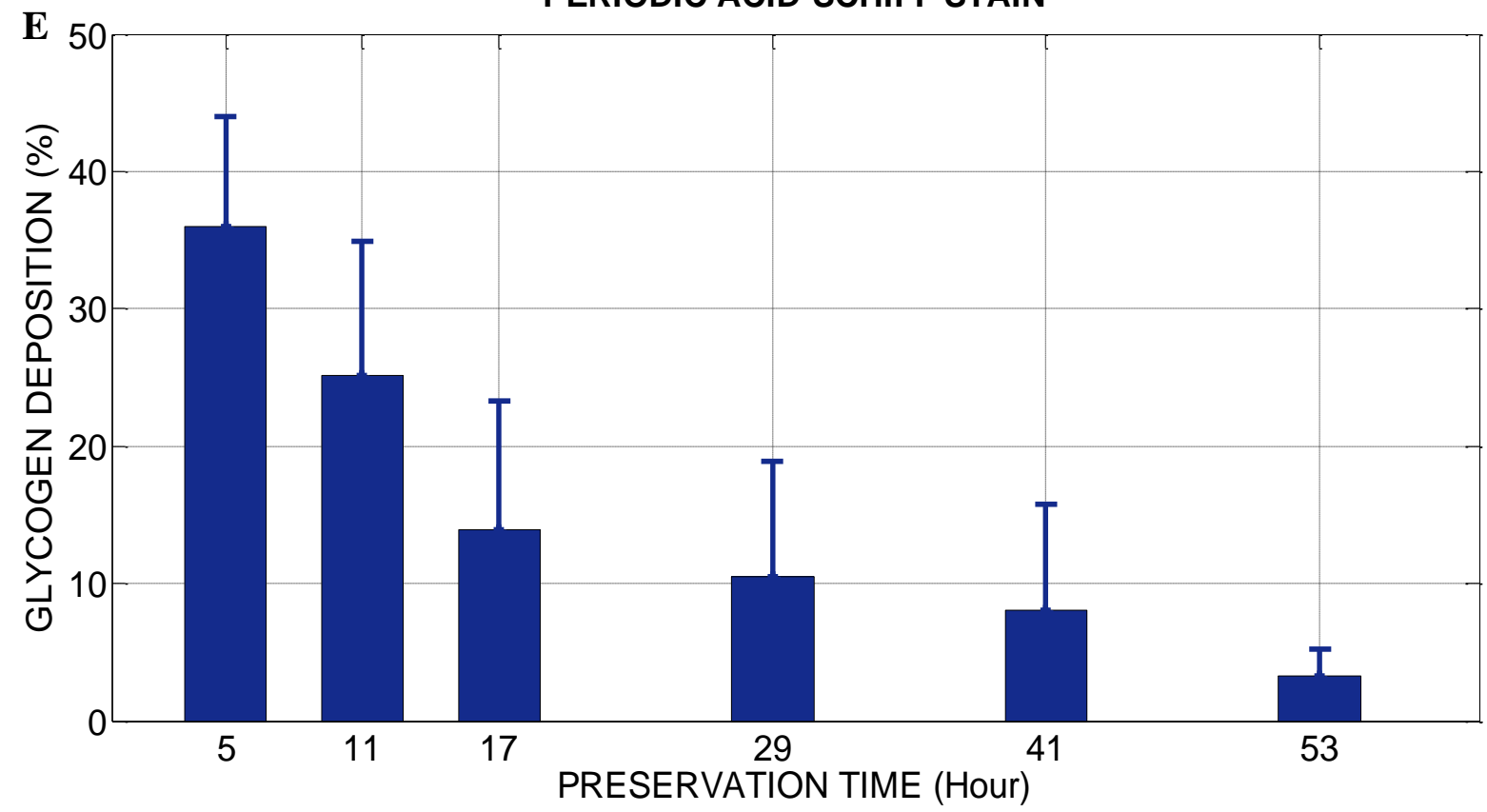

Figure 11. (A, C) The exemplar images of the sections stained with the Periodic AcidSchiff and preserved for PT $=5 \mathrm{hrs}$ and PT $=53 \mathrm{hrs}$. (B, D) The image analysis software measures the magenta colored regions. (E) The change in the deposited glycogen level (average of 3 animals) as a function of preservation time shows dramatic change in the glycogen deposition in the cells. 
Table 1. The hyperelastic material coefficients and the linear elastic modulus of bovine liver (average of 3 animals) for different preservation periods.

\begin{tabular}{|c|c|c|c|c|c|c|}
\hline $\begin{array}{l}\text { Preservation } \\
\text { Time } \\
\text { (PT) }[\text { Hour] }\end{array}$ & $\mathrm{C}_{10}$ & $\mathrm{C}_{01}$ & $\mathrm{C}_{20}$ & $\mathrm{C}_{11}$ & $\mathrm{C}_{02}$ & $\begin{array}{c}\text { Linear Elastic } \\
\text { Modulus, E } \\
{[\mathrm{kPa}]}\end{array}$ \\
\hline 5 & $\begin{array}{c}130.8 \\
\pm 65.5\end{array}$ & $\begin{array}{r}130.2 \\
\pm 47.4\end{array}$ & $\begin{array}{l}200.9 \\
\pm 78.6\end{array}$ & $\begin{array}{c}387.1 \\
\pm 38.5\end{array}$ & $\begin{array}{c}440.3 \\
\pm 148.7\end{array}$ & $\begin{array}{r}1.57 \\
\pm 1.1\end{array}$ \\
\hline 11 & $\begin{array}{c}86.9 \\
\pm 39.1\end{array}$ & $\begin{array}{c}196.4 \\
\pm 97\end{array}$ & $\begin{array}{l}1063.3 \\
\pm 66.5\end{array}$ & $\begin{array}{c}252.3 \\
\pm 194.3\end{array}$ & $\begin{array}{l}584.6 \\
\pm 103\end{array}$ & $\begin{array}{r}1.70 \\
\pm 1.1\end{array}$ \\
\hline 17 & $\begin{array}{c}447.7 \\
\pm 250.5\end{array}$ & $\begin{array}{c}44.1 \\
\pm 22.1\end{array}$ & $\begin{array}{r}1452.7 \\
\pm 312.7\end{array}$ & $\begin{array}{c}413.8 \\
\pm 141.9\end{array}$ & $\begin{array}{c}706.8 \\
\pm 155.9\end{array}$ & $\begin{array}{r}2.95 \\
\pm 2.2\end{array}$ \\
\hline 29 & $\begin{array}{c}364.1 \\
\pm 78.4\end{array}$ & $\begin{array}{c}953.5 \\
\pm 167.3\end{array}$ & $\begin{array}{r}1001.8 \\
\pm 218.2\end{array}$ & $\begin{array}{r}1004.0 \\
\pm 284.6\end{array}$ & $\begin{array}{r}1061.0 \\
\pm 261.6\end{array}$ & $\begin{array}{c}7.91 \\
\pm 1.8\end{array}$ \\
\hline 41 & $\begin{array}{l}2100.3 \\
\pm 92.1\end{array}$ & $\begin{array}{r}1391.7 \\
\pm 206.9\end{array}$ & $\begin{array}{l}725.8 \\
\pm 84\end{array}$ & $\begin{array}{c}799.8 \\
\pm 125.1\end{array}$ & $\begin{array}{c}579.1 \\
\pm 196.1\end{array}$ & $\begin{array}{l}20.95 \\
\pm 2.9\end{array}$ \\
\hline 53 & $\begin{array}{c}4435.2 \\
\pm 263.3\end{array}$ & $\begin{array}{r}1165.6 \\
\pm 488.5\end{array}$ & $\begin{array}{c}72.2 \\
+\quad 32.4\end{array}$ & $\begin{array}{l}489.4 \\
\pm 92.6\end{array}$ & $\begin{array}{c}606.0 \\
\pm 184.2\end{array}$ & $\begin{array}{l}33.60 \\
\pm 3.7\end{array}$ \\
\hline
\end{tabular}


Table 2. The viscoelastic material coefficients and settling time of bovine liver (average of 3 animals) for different preservation periods.

\begin{tabular}{|c|c|c|c|c|c|c|c|}
\hline $\begin{array}{l}\text { Preservation } \\
\text { Time } \\
\text { (PT) [Hour] }\end{array}$ & $\alpha_{1}$ & $\alpha_{2}$ & $\alpha_{3}$ & $\tau_{1}$ & $\tau_{2}$ & $\tau_{3}$ & $\begin{array}{c}\begin{array}{c}\text { Settling } \\
\text { Time } \\
(\mathrm{ST}) \\
{[\mathrm{Sec}]}\end{array} \\
\end{array}$ \\
\hline 5 & $\begin{array}{c}0.44 \\
\pm 0.03\end{array}$ & $\begin{array}{c}0.07 \\
\pm 0.01\end{array}$ & $\begin{array}{c}0.28 \\
\pm 0.02\end{array}$ & $\begin{array}{c}6.65 \\
\pm 0.41\end{array}$ & $\begin{array}{l}37.10 \\
\pm 3.75\end{array}$ & $\begin{array}{l}58.80 \\
\pm 6.32\end{array}$ & $\begin{array}{c}198 \\
\pm 3.8\end{array}$ \\
\hline 11 & $\begin{array}{c}0.42 \\
\pm 0.04\end{array}$ & $\begin{array}{c}0.08 \\
\pm 0.02\end{array}$ & $\begin{array}{c}0.36 \\
\pm 0.03\end{array}$ & $\begin{array}{c}6.74 \\
\pm 0.77\end{array}$ & $\begin{array}{l}46.65 \\
\pm 4.64\end{array}$ & $\begin{array}{c}64.83 \\
\pm 1.50\end{array}$ & $\begin{array}{c}261 \\
\pm 2.7\end{array}$ \\
\hline 17 & $\begin{array}{c}0.40 \\
\pm 0.02\end{array}$ & $\begin{array}{c}0.08 \\
\pm 0.01\end{array}$ & $\begin{array}{c}0.39 \\
\pm 0.02\end{array}$ & $\begin{array}{c}6.75 \\
\pm 1.46\end{array}$ & $\begin{array}{l}58.63 \\
\pm 5.08\end{array}$ & $\begin{array}{r}66.39 \\
\pm 2.20\end{array}$ & $\begin{array}{c}289 \\
\pm 4.6\end{array}$ \\
\hline 29 & $\begin{array}{c}0.37 \\
\pm 0.04\end{array}$ & $\begin{array}{c}0.08 \\
\pm 0.02\end{array}$ & $\begin{array}{c}0.37 \\
\pm 0.03\end{array}$ & $\begin{array}{c}6.45 \\
\pm 1.22\end{array}$ & $\begin{array}{r}65.29 \\
\pm 10.1\end{array}$ & $\begin{array}{l}76.18 \\
\pm 5.87\end{array}$ & $\begin{array}{c}295 \\
\pm 3.2\end{array}$ \\
\hline 41 & $\begin{array}{c}0.32 \\
\pm 0.01\end{array}$ & $\begin{array}{c}0.06 \\
\pm 0.01\end{array}$ & $\begin{array}{c}0.38 \\
\pm 0.09\end{array}$ & $\begin{array}{c}6.95 \\
\pm 0.47\end{array}$ & $\begin{array}{c}68.16 \\
\pm 7.8\end{array}$ & $\begin{array}{r}84.23 \\
\pm 3.52\end{array}$ & $\begin{array}{c}303 \\
\pm 5.1\end{array}$ \\
\hline 53 & $\begin{array}{c}0.30 \\
\pm 0.06\end{array}$ & $\begin{array}{c}0.08 \\
\pm 0.01\end{array}$ & $\begin{array}{c}0.37 \\
\pm 0.06\end{array}$ & $\begin{array}{c}5.70 \\
\pm 0.62\end{array}$ & $\begin{array}{l}54.87 \\
\pm 9.2\end{array}$ & $\begin{array}{c}87.93 \\
\pm 12.53\end{array}$ & $\begin{array}{c}309 \\
\pm 2.9\end{array}$ \\
\hline
\end{tabular}


Table 3. The histological properties of bovine liver (average of 3 animals) for different preservation periods.

\begin{tabular}{|c|c|c|c|c|}
\hline $\begin{array}{l}\text { Preservation } \\
\text { Time } \\
\text { (PT) }[\text { Hour }]\end{array}$ & $\begin{array}{c}\text { Apoptotic } \\
\text { Cell } \\
\text { (AC) } \\
\text { [Count] } \\
\end{array}$ & $\begin{array}{c}\text { Fiber } \\
\text { Tissue } \\
(\mathrm{FT})[\%]\end{array}$ & $\begin{array}{l}\text { Sinusoidal } \\
\text { Dilatation } \\
\text { (SD) }[\%]\end{array}$ & $\begin{array}{c}\text { Glycogen } \\
\text { Deposition } \\
\text { (GD) [\%] }\end{array}$ \\
\hline 5 & $\begin{array}{c}12.93 \\
\pm 6\end{array}$ & $\begin{array}{r}6.17 \\
\pm 2.8 \\
\end{array}$ & $\begin{array}{r}28.34 \\
\pm 13.2 \\
\end{array}$ & $\begin{array}{l}35.99 \\
\pm 7.9 \\
\end{array}$ \\
\hline 11 & $\begin{array}{c}25.5 \\
\pm 14.2\end{array}$ & $\begin{array}{c}6.5 \\
\pm 2.9\end{array}$ & $\begin{array}{c}30.82 \\
\pm 11\end{array}$ & $\begin{array}{c}25.14 \\
\pm 9.8\end{array}$ \\
\hline 17 & $\begin{array}{c}36.96 \\
\pm 11\end{array}$ & $\begin{array}{l}10.15 \\
\pm 4.5\end{array}$ & $\begin{array}{c}30.34 \\
\pm 5.9\end{array}$ & $\begin{array}{l}13.88 \\
\pm 9.4\end{array}$ \\
\hline 29 & $\begin{array}{r}47.53 \\
\pm 13.1\end{array}$ & $\begin{array}{l}14.22 \\
\pm 6.7\end{array}$ & $\begin{array}{c}37.1 \\
\pm 13.2\end{array}$ & $\begin{array}{l}10.48 \\
\pm 8.4\end{array}$ \\
\hline 41 & $\begin{array}{r}44.43 \\
\pm 12.2 \\
\end{array}$ & $\begin{array}{r}15.29 \\
\pm 7.6 \\
\end{array}$ & $\begin{array}{r}32.33 \\
\pm 5.6 \\
\end{array}$ & $\begin{array}{c}8.1 \\
\pm 7.63 \\
\end{array}$ \\
\hline 53 & $\begin{array}{l}43.96 \\
\pm 9.3\end{array}$ & $\begin{array}{l}15.98 \\
\pm 6.3\end{array}$ & $\begin{array}{l}38.92 \\
\pm 6.6\end{array}$ & $\begin{array}{l}3.31 \\
\pm 1.9\end{array}$ \\
\hline
\end{tabular}


Table 4. The correlation coefficients, $\mathrm{r}_{\mathrm{s}}$, and the strength of correlation (0-0.19: 'very weak', 0.20-0.39: 'weak', 0.40-0.59: 'moderate', 0.60-0.79: 'strong', 0.80-1.0: 'very strong', SI: Statistically Insignificant) between the mechanical and histological properties of bovine liver.

\begin{tabular}{|c|c|c|c|c|c|c|c|}
\hline $\begin{array}{c}\text { Correlation } \\
\text { Coefficient } \\
\left(\mathrm{r}_{\mathrm{s}}\right) \\
\end{array}$ & $\begin{array}{c}\text { Apoptotic } \\
\text { Cell } \\
\text { Count }\end{array}$ & $\begin{array}{c}\text { Connective } \\
\text { Tissue }\end{array}$ & $\begin{array}{l}\text { Sinusoidal } \\
\text { Dilatation }\end{array}$ & $\begin{array}{c}\text { Glycogen } \\
\text { Deposition }\end{array}$ & $\begin{array}{l}\text { Young's } \\
\text { Modulus }\end{array}$ & $\begin{array}{c}\text { Fracture } \\
\text { Toughness }\end{array}$ & $\begin{array}{c}\text { Settling } \\
\text { Time }\end{array}$ \\
\hline $\begin{array}{c}\text { Apoptotic } \\
\text { Cell } \\
\text { Count }\end{array}$ & - & 0.84 & SI & -0.48 & 0.51 & 0.68 & 0.69 \\
\hline $\begin{array}{l}\text { Connective } \\
\text { Tissue }\end{array}$ & $\begin{array}{c}\text { Very } \\
\text { Strong }\end{array}$ & - & SI & -0.66 & 0.74 & 0.80 & 0.83 \\
\hline $\begin{array}{l}\text { Sinusoidal } \\
\text { Dilatation }\end{array}$ & SI & SI & - & -0.53 & SI & SI & SI \\
\hline $\begin{array}{l}\text { Glycogen } \\
\text { Deposition }\end{array}$ & Moderate & Strong & Moderate & - & -0.90 & -0.92 & -0.87 \\
\hline $\begin{array}{l}\text { Young's } \\
\text { Modulus }\end{array}$ & Moderate & Strong & SI & $\begin{array}{c}\text { Very } \\
\text { Strong }\end{array}$ & - & 0.87 & 0.81 \\
\hline $\begin{array}{l}\text { Fracture } \\
\text { Toughness }\end{array}$ & Strong & $\begin{array}{c}\text { Very } \\
\text { Strong }\end{array}$ & SI & $\begin{array}{c}\text { Very } \\
\text { Strong }\end{array}$ & $\begin{array}{c}\text { Very } \\
\text { Strong }\end{array}$ & - & 0.90 \\
\hline $\begin{array}{l}\text { Settling } \\
\text { Time }\end{array}$ & Strong & $\begin{array}{l}\text { Very } \\
\text { Strong }\end{array}$ & SI & $\begin{array}{l}\text { Very } \\
\text { Strong }\end{array}$ & $\begin{array}{l}\text { Very } \\
\text { Strong }\end{array}$ & $\begin{array}{l}\text { Very } \\
\text { Strong }\end{array}$ & - \\
\hline
\end{tabular}


Table 5. The sensitivity values calculated for histological and mechanical properties.

\begin{tabular}{|c|c|c|c|c|c|c|c|}
\hline $\begin{array}{c}\text { Preservation } \\
\text { Time (PT) }\end{array}$ & $\begin{array}{c}\text { Apoptotic } \\
\text { Cell } \\
\text { Count }\end{array}$ & $\begin{array}{c}\text { Connective } \\
\text { Tissue }\end{array}$ & $\begin{array}{l}\text { Sinusoidal } \\
\text { Dilatation }\end{array}$ & $\begin{array}{c}\text { Glycogen } \\
\text { Deposition }\end{array}$ & $\begin{array}{l}\text { Young's } \\
\text { Modulus }\end{array}$ & $\begin{array}{c}\text { Fracture } \\
\text { Toughness }\end{array}$ & $\begin{array}{c}\text { Settling } \\
\text { Time }\end{array}$ \\
\hline 5 & - & - & - & - & - & - & - \\
\hline 11 & $\begin{array}{r}16.19 \\
\pm 1.75\end{array}$ & $\begin{array}{c}0.87 \\
\pm 0.09\end{array}$ & $\begin{array}{c}1.46 \\
\pm 0.16\end{array}$ & $\begin{array}{l}-5.01 \\
\pm 0.55\end{array}$ & $\begin{array}{c}1.49 \\
\pm 0.16\end{array}$ & $\begin{array}{r}10.76 \\
\pm 1.19\end{array}$ & $\begin{array}{c}5.30 \\
\pm 0.58\end{array}$ \\
\hline 17 & $\begin{array}{c}7.49 \\
\pm 0.83\end{array}$ & $\begin{array}{c}9.35 \\
\pm 1.03\end{array}$ & $\begin{array}{l}-0.26 \\
\pm 0.02\end{array}$ & $\begin{array}{l}-7.46 \\
\pm 0.82\end{array}$ & $\begin{array}{r}12.26 \\
\pm 1.36\end{array}$ & $\begin{array}{c}4.64 \\
\pm 0.51\end{array}$ & $\begin{array}{c}1.78 \\
\pm 0.19\end{array}$ \\
\hline 29 & $\begin{array}{c}2.38 \\
\pm 0.26\end{array}$ & $\begin{array}{c}3.34 \\
\pm 0.37\end{array}$ & $\begin{array}{r}1.85 \\
\pm 0.2\end{array}$ & $\begin{array}{l}-2.04 \\
\pm 0.22\end{array}$ & $\begin{array}{r}13.98 \\
\pm 1.55\end{array}$ & $\begin{array}{c}1.68 \\
\pm 0.18\end{array}$ & $\begin{array}{c}0.14 \\
\pm 0.01\end{array}$ \\
\hline 41 & $\begin{array}{c}-0.54 \\
\pm 0.06\end{array}$ & $\begin{array}{c}0.58 \\
\pm 0.06\end{array}$ & $\begin{array}{l}-1.07 \\
\pm 0.11\end{array}$ & $\begin{array}{l}-1.89 \\
\pm 0.21\end{array}$ & $\begin{array}{c}13.75 \\
\pm 1.24\end{array}$ & $\begin{array}{c}0.86 \\
\pm 0.09\end{array}$ & $\begin{array}{c}0.25 \\
\pm 0.02\end{array}$ \\
\hline 53 & $\begin{array}{l}-0.08 \\
\pm 0\end{array}$ & $\begin{array}{c}0.41 \\
\pm 0.04\end{array}$ & $\begin{array}{l}1.7 \\
\pm 0.18\end{array}$ & $\begin{array}{l}-4.92 \\
\pm 0.54\end{array}$ & $\begin{array}{c}5.03 \\
\pm 0.55\end{array}$ & $\begin{array}{l}-0.31 \\
\pm 0.03\end{array}$ & $\begin{array}{c}0.16 \\
\pm 0.01\end{array}$ \\
\hline
\end{tabular}

